\title{
REGIJA IN REGIONALNA STRUKTURA SLOVENIJE
}

\author{
Marijan M. KLEMENČıč \\ Oddelek za geografijo, Filozofska fakulteta, Univerza v Ljubljani \\ Aškerčeva 2, 1000 Ljubljana, Slovenija \\ e-mail: marijan.klemencic@guest.arnes.si \\ Izvirni znanstveni članek \\ COBISS 1.01
}

\section{Izvleček}

Regija kot središčni pojem geografije je obravnavana v treh sklopih. V prvem delu so predstavljeni poglavitni pogledi na regijo od Hartshorna do Paasija, drugi del vsebuje kritični pretres obravnave regije v slovenski geografiji, v tretjem delu pa so nakazani nekateri geografski elementi, ki opredeljujejo regionalno strukturo Slovenije.

Ključne besede: regija, regionalna struktura, regionalna identiteta, Slovenija.

\section{REGION AND REGIONAL STRUCTURE OF SLOVENIA}

\begin{abstract}
Region as the central conception of geography is treated in the frame of three parts. In the first part the most exposed views on the region from Hartshorne to Paasi are represented. The second part contains a critical examination of use of the term region in Slovenian geography. Some geographical elements, defining the regional structure of Slovenia, are indicated in the last part of the paper.
\end{abstract}

Key words: region, regional structure, regional identity, Slovenia. 


\section{UVOD}

"Sposobnost geografov $k$ razčlenitvi geografije na posamezne discipline je bila veliko večja, kot je sposobnost sestavljanja in postavljanja naših zgradb nazaj v realnost.” (Hägerstrand, 1975)

Kljub temu, da je regija eden izmed temeljnih geografskih pojmov, pa je njegova vsebina med vsemi geografskimi pojmi najmanj jasna; celo več, noben drug pojem ni obsojen na tako različna, pogosto celo kontroverzna razumevanja. Če nekateri raziskovalci ne priznavajo realnega obstoja regije, ali zahajajo celo v abstrahiranje naravnega okolja in (pretirano) izpostavljanje socialnih procesov, je potrebno spomniti na pojem, ki ima sicer zelo posplošen pomen, a nakazuje potrebo po celovitem obravnavanju zemeljskega površja: organizacija prostora. Spomnimo se le nekaterih najbolj poznanih raziskovalcev omenjene tematike: von Thünena, Christallerja, Löscha, Böscha, Haggetta in številnih francoskih geografov. Obsežna Encyclopédie de géographie (1992) neposredno in posredno kaže na to, da je geografija veda o organizaciji geografskega prostora, v katerem -če je znanstvena disciplinaišče zakonitosti/splošnosti/urejenost. Že samo to dejstvo izpostavlja regijo kot nujen (temeljni) sestavni del geografskega preučevanja.

Na vsebino regije je vezana skoraj vsa geografija, posebno pa vsebina in način organiziranja pokrajine. Za polno razumevanje regije bi bilo potrebno podrobno preučiti zgradbo pokrajine, kar pa je naloga, ki jo rešuje vsa geografska znanost dolga desetletja. Zato se nam ne zdi prav nič pregrešna misel Johnstona, znanega filozofa geografije: "Ne potrebujemo regionalne geografije, potrebujemo pa regije v geografiji." (Johnston, 1991, str. 67).

V prispevku želimo opozoriti na središčni značaj regije v geografiji, iz česar izhaja tudi upanje na celovitejšo obravnavo zemeljskega površja oziroma po Ilešiču v določeno obliko reintegracije geografije.

Namen prvega dela razprave je $\mathrm{v}$ tem, da predstavimo poglavitne poglede na regijo, kot so se izoblikovali v svetovni geografiji, ter da izpostavimo ključne pojme, dileme in probleme, povezane s pojmom regija. Zaradi lažje preglednosti tematike in prikaza razlik v razumevanju vsebine regije v zadnji polovici 20. in v začetku 21. stoletja sta izpostavljena pogleda dveh avtoritet: Hartshorna in Paasija, nato pa so nanizani pogledi številnih tujih geografov o regiji, da bi dobili čim širši vpogled v raznovrstnost pogledov na temeljni geografski pojem. Tematika je obravnavana deloma po problemskih sklopih, deloma pa razvojno.

V drugem delu je predstavljen poskus kritičnega pretresa obravnave regije v slovenski geografiji, tako s teoretičnega kot tudi praktičnega vidika (regionalizacij).

Nakazani so nekateri poglavitni elementi, ki jih je potrebno upoštevati pri opredeljevanju regij v Sloveniji.

Na koncu je podanih nekaj izhodišč, ki nakazujejo smeri, v katerih se (naj bi se) razvijajo regije v Sloveniji.

Glede na nizko teoretično raven obravnave vsebine regije, regionalizacije in regionalne geografije v slovenski geografski srenji, prispevek predstavlja izhodišče in vzpodbudo za 
teoretsko bolj poglobljeno slovensko geografijo in razširitev njenih horizontov na mednarodna obzorja.

\section{REALNI SVET, NJEGOVA UREJENOST IN REGIJA}

"Pomen in razumevanje koncepta regije sta se spreminjala, kakor se je spreminjalo razumevanje in opisovanje sveta v družbeni geografiji.” (Sagan, 2004, str. 141)

Tehnološki napredek in razvoj družbe sta z industrijsko revolucijo neverjetno pospešila preobrazbo zemeljskega površja. Dotedanja dvostopenjska organiziranost pokrajine: na eni strani na osnovi preprostih načinov obdelovanja zemlje temelječi agrarni del družbe, ki je oblikoval mozaično pokrajinsko strukturo majhnih, sorazmerno zaprtih vaških/farnih skupnosti, na drugi strani pa mreža mest in trgov, ki je prek trgovskih povezav predstavljala nosilno strukturo pokrajin. Meje so bile jasne, tako med vaškimi skupnostmi, med mestom in podeželjem, med posestvi zemljiških gospodov, med upravnimi enotami itd. Območja skupnega življenja kot prizorišča, kjer je odnos med človekom in okoljem oblikoval določen časovno-prostorski specifični način življenja (genre de vie), bi z Blachem lahko poimenovali kot regije. Ponavljajoče izkušnje pri reševanju skupnih življenjskih problemov v okviru nekega geografskega okolja je povzročilo razvoj zavedanja skupnosti, ki ima izrazito ekološki poudarek.

$\mathrm{Z}$ industrijsko revolucijo so lahko razpoznavne meje fizičnega okolja začele bledeti. Prevlada točkovnega (industrijskega) načina proizvodnje je namesto razpršene (agrarne) proizvodnje težila k zgoščevanju in s tem slabila razpoznavnost starih pokrajinskih enot; nadomeščala jih je s pogosto spreminjajočimi se obsegi gravitacijskih območij industrijskih središč. Spremenil se je način sporazumevanja med ljudmi, povečala se je delitev dela in z njo socialna diferenciacija. Navidezno se je sprostila navezanost ljudi na (domači) kraj. Sodobna delitev dela razbija nekdanje regionalne skupnosti in oblikuje različne skupine in skupnosti znotraj nekega območja.

Porast mednarodnih povezav (trgovskih, finančnih, osebnih, informacijskih, političnih), posebno z globalizacijo, je kot povratni učinek povzročil dvig novega vala regionalizma, ki podčrtuje pomen regij in regionalne identitete. Hkrati je regija postala tržno blago; različni dejavniki moči skušajo uveljavljati svoje "regije" z namenom, da bi uveljavljali svoje interese (turistične, planerske, razvojne, politične in druge regije).

V času industrijske družbe je bila država ključni okvir za regijo in oblikovanje identitete. Globalizacija je sprožila reakcijo v obliki prepoznavanja manjših enot (glokalizacija), v Evropi pa val regionalizma (Evropa regij). Globalizacija, ki jo označujejo spremembe v razvoju kapitalizma (povezave, mobilnost) se presenetljivo uveljavlja in vzdržuje prek sodelovanja kultur in identitet, ki se izražajo v mnogostopenjskem omrežju.

Izrazi kot omrežje, tokovi, obvladovanje so ključni v retoriki globalizacije. Čeprav države ostajajo pomembni družbenogospodarski in politični dejavniki sodobnega sveta, pa so njihove meje vedno bolj porozne, zlasti v gospodarskem in političnem pogledu. Pretoki naddržavnega kapitala, prepletenost gospodarskih povezav, pa tudi politična povezovanja pre- 
razporejajo pomen in značaj ravni, od lokalne do globalne. Med posameznimi prostorskimi hierarhičnimi stopnjami so predvsem pomembni tokovi/povezave, saj ravno oni dajejo območjem dinamiko in s tem stopnjo samostojnega oblikovanja identitete. $\mathrm{S}$ tem pa se spreminja pogled na regijo. $Z$ globalnim kapitalizmom znova stopa $\mathrm{v}$ ospredje pomen regij, a $\mathrm{v}$ novi luči politično-ekonomskih usmeritev v razumevanju regije. Regije postajajo vse bolj instrument vplivanja/delovanja različnih dejavnikov, kar se kaže posebno na vse močnejši spregi med identiteto in ideologijo.

Uitermark (2002, str. 744-745) pritrjuje gornjim mnenjem, a gre v posploševanju nekoliko dlje. Fordistično obdobje je krepilo moč države, novo obdobje kapitalistične akumulacije (globalizacija) pa izpostavi regije, ki postanejo motor za globalno gospodarsko rast, medtem ko je moč nacionalnih držav omejena s procesi nadnacionalnega povezovanja in internacionalizacijo gospodarstva. V tej luči so lažje razumljive sodobne smeri gledanja na regijo kot na stik (bojišče) med globalnimi in lokalnimi procesi, pa tudi na prizadevanja dejavnikov moči po uveljavljanju svojih interesov v okviru regij.

Nekateri pogledi na sodobno družbo v svoji radikalnosti želijo izstopiti iz "tiranije" fizičnega okolja, ki ga predstavlja razdalja in se osvoboditi geografskih konceptov. Takšen pogled ima po navedbi Paasija (2004, str. 541) Latour, ki pravi, da je sodobna družba vlaknatega, kapilarnega značaja, zato ni ujetnik stopenj, plasti, teritorijev, sfer, kategorij, struktur, sistemov. V ospredje postavlja mreže kot nosilke razvoja sodobne družbe, ker omogočajo druženja, povezovanja. Vsekakor je takšno gledanje izrazito enostransko (indeterministično).

Z globalizacijo regija torej ni izginila; nasprotno, dobila je nove pomene, nove funkcije, spremenil pa se je tudi njen ustroj v primerjavi z regijami izpred nekaj desetletij.

Tako za sorodno (interdisciplinarno) regionalno znanost Coffey (1992) meni, da bo v prihodnosti igrala glavno vlogo na področju ekonomskih in družbenih ved, a pod pogojem, da bo odprta za sodobne probleme, da bo ohranila svoj interdisciplinarni značaj in znanstveno strogost. Enako velja za regionalno geografijo in regijo v njenem okviru.

Nikakor pa ne smemo zanemariti tudi problema velikosti (skale) regije, ki je posledica prevrednotenja vseh temeljnih geografskih kategorij, od kraja, lokalnosti, do regije, kar vse povezuje izraz obseg (skala).

\section{REGIJA OD HARTSHORNA...}

"Od samih začetkov sodobne geografije so se geografi spopadali s težavami v zvezi z naravo prostorskih enot, ki sestavljajo njihov objekt preučevanja - svet.” (Hartshorne, 1946, str. 250)

Pogled na regijo je dejansko pogled na vsebino pokrajine, gledan skozi oči geografa. Posameznik je ujetnik/proizvod dobe in okolja, zato so razumljive velike razlike v simultanih pogledih na regijo, še bolj pa pogledi v različnih obdobjih. Hartshorne (1946) je v enem izmed temeljnih del svetovne geografije: The nature of geography kritično ovrednotil dotedanji razvoj geografije, med drugim tudi regionalne geografije in z njo povezanih temeljnih pojmov. Hartshorne je predstavil in ovrednotil dotedanje različne opredelitve regije. Oglejmo si njegove poglede na regijo. 
Regija (Landschaft) naj ne bi bila organizem, konkreten objekt oziroma enkratna (individualizirana) celota, pač pa arbitrarno izbran del pokrajine.

Geografska regija prikazuje pokrajinske pestrosti na preveč poenostavljen način, predvsem na način, kakršnega si je zamislil raziskovalec, zato je regija le konstrukt.

Ker geografski podatki niso tako enoznačni in jasni, kot jih poznajo astronomi ali biologi, jih mora geograf, na primer za klasifikacijo regij kot objektov, ovrednotiti (podvreči intelektualni dejavnosti), kar pa pomeni dobršno mero subjektivizma.

Regijo lahko primerjamo z živim organizmom, saj ima obliko, zgradbo in funkcijo, zato govorimo o anatomiji območja (Sauer). Vidal de la Blache govori o "zemeljskih organizmih", drugi o "Raumorganismus"; to pa pomeni, da ima regija -tako kot organizmi- moč prilagajanja, kohezije, odzivanja, ponovnega oblikovanja. Bürger postavi ostro ločnico med regijo v smislu celote (Gestalt) in organizmom. V obeh primerih prepletanje številnih dejavnikov sicer oblikuje celoto, ki je sposobna življenja le pri organizmih. To je Pencku raz$\log$ za pogled, da je organizem nedeljiv v nasprotju z zemeljskim površjem, ki ga lahko členimo na vse manjše enote. Analogijo $\mathrm{z}$ organizmi pa lahko najdemu pri obravnavi rasti. Kot rastlina tudi regija raste iz svojih potencialov, a sprejema tudi zunanje razvojne impulze. Regija ima neke značilnosti človeškega bitja: fizična zgradba se prepleta s kulturnimi elementi.

Harsthornovo gledanje na regijo je precej skeptično, ker naj bi bila njena opredelitev podvržena preveliki subjektivnosti. Vsaka prostorska enota ima pomembne odnose z vsemi sosednjimi enotami, zato so opredeljene regionalne enovitosti le mentalni konstrukti; regionalna enovitost naj bi bila le $\mathrm{v}$ naših glavah. Razmejevanje regij naj bi potekalo brez napora. Tako dobljene površinske enote, znotraj sebe močno organizirane in jasno ločene od sosednjih, na zemljevidu predstavljajo mozaik zemeljskega površja. Prava slika se vidi od daleč, bolj pa ko se približujemo zemljevidu, le-ta predstavlja vedno večji ponaredek realnosti.

Poleg slike kot prispodobe zgradbe zemeljskega površja Hartshorne govori o mozaiku. Vsak delček slike je posebna kombinacija barv in črt in je zato nekaj posebnega; noben delček ne predstavlja jasne individualne enote. Mozaik pa je nasprotno sestavljen iz niza individualnih koščkov, za katere ni nujno, da imajo posebno individualnost $\mathrm{v}$ smislu enkratnosti, saj so nekateri lahko med seboj enaki po barvi in obliki. Kot je jasno razvidno, imajo posamični delčki slike/mozaika različen značaj. Hartshorne to prenaša na pokrajino in izpostavlja razlikovanje med pojmoma enkraten in posamičen. Bolj problematičen od omenjenih pojmov je pojem enota (unit, Einheit), posebno v pridevniški obliki enoten, enoličen (einheitlich).

Penck je od psihologov prevzel pojem Gestalt, da je z njim izrazil enotno obliko večjih območij, ki so sestavljena iz svojstveno urejenih regij. Gestalt naj bi bil dinamična struktura, $\mathrm{v}$ katero vstopajo posamezni dejavniki $\mathrm{z}$ učinkovanjem na vse ostale in jih lahko razumemo le z vidika celote. Gestalt je za psihologe na splošno isto kot Ganzheit. S tega vidika je regija izrazito kompleksen pojav, tudi če ji zanikamo enkraten značaj. Ob tem ne smemo prezreti dejstva, da je Gestalt terminologija nemških geografov dosegla višek v razpravah o nemškem življenjskem prostoru (Lebensraum). Problem pojmov kot "psihična celota", Gestalt, "regionalni značaj", "duša/duh regije" je bil poleg tega, da so včasih vklju- 
čevali mistične oznake, nedvomno $\mathrm{v}$ tem, da je bil odnos med regijo in njenimi prebivalci skrčen na psihološki problem, ne pa na trajno vzdrževanje regionalnega zavedanja s strani delovanja institucij (Paasi, 1986, str.137).

Za Hartshorna regija ni določena v naravi ali v resničnosti. Nasprotno, on je pomemben predstavnik zagovornikov regije kot miselnega konstrukta, kot predstave $\mathrm{v}$ glavi raziskovalca. Regije naj bi bile abstrakcije. Kot oblika teritorialnosti lahko postanejo napolnjene s čustvi in podrejene intelektualni naravnanosti raziskovalca, zato jih uporabljamo najprej kot miselna orodja, kot sredstva za analizo in sintezo. Tako ne moremo upati, da bi jih z raziskavo "odkrili". Iščemo le najbolj inteligentna izhodišča za določevanje meja, s katerimi delimo svet na regije.

Hartshornov pristop je horološki: regija je območje specifične lokacije, ki je na določen način različna od drugih območij in je tako obsežna, do kamor seže to razlikovanje.

Poleg povzemanja glavnih pristopov $\mathrm{k}$ regionalni geografiji in regiji je Harsthornova posebna zasluga $\mathrm{v}$ tem, da je izpostavil in opredelil najpomembnejše pojme, povezane $\mathrm{z}$ regijo: kriteriji za regionalizacijo, meje, enkratnost, enotnost, prehodnost. Ob zelo širokem pogledu na pokrajino pa ob primeru regije lahko brez prevelikega pretiravanja rečemo, da se je Hartshorne močno oklepal formalističnega (pozitivističnega) pristopa. Med drugim omenja, da "mora vsaka veda, ki preučuje realnost, uporabljati koncepte, ki dejansko predstavljajo deformacijo resničnosti" (1946, str. 286). Regionalizacija je zanj predvsem orodje za izpeljavo raziskovalčevih pogledov (konceptov) na pokrajino. S tem pogledom zaokrožuje dobro stoletje dolge poglede na regijo. Intenzivne družbenogospodarske in prostorske spremembe so regiji namenile novo vsebino: namesto anonimnega, poljubno izbranega dela zemeljskega površja (objekta) se je spremenila v pomemben pokrajinski člen (subjekt).

\section{... DO PAASIJA}

"Koncept regije je bil in je še vedno ena od temeljnih kategorij geografske misli, skupaj z drugimi kot sta prostor in kraj ter njune izpeljanke: razdalja, lokacija in dostopnost". (Paasi, 1986, str. 106)

Podobno delo, kot ga je Harsthorne opravil za celotno geografijo, je Paasi naredil za regijo. Temeljito je pretresel vsebinske, teoretske in metodološke vidike regije, kot so se pojavljale v svetovni literaturi nekako po drugi svetovni vojni. Paasi je šel še precej dlje; izdelal je svoj pogled na regijo, njeno naravo in njen razvoj. Njegov pogled na regijo je zelo odmeven, kar je vidno iz pogostega citiranja njegovih del v najbolj znanih geografskih revijah.

Paasijevo delo ima posebno težo zato, ker je bistveno prispeval $\mathrm{k}$ renesansi in prevrednotenju regije v svetovni geografiji. Regionalna geografija je namreč skoraj celo drugo polovico 20. stoletja ostajala v senci/nemilosti "sodobnih" geografskih konceptov. Ves ta čas je bila skupaj z regijo pastorka vede, za nekatere celo fosil ali nepotreben balast. Le redki posamezniki so se oglašali s poskusi teoretske obravnave regionalne geografije. Regije so postale objekt samovoljnega opredeljevanja; s tem je njihova obravnava dejansko postala neznanstvena. Praksa v regionalni geografiji je bila v dobršni meri še naprej v kopičenju velikih količin podatkov, njihovem opisovanju in odsotnosti teorije. 
Pri predstavitvi regije Paasi (1986) izhaja iz dejstva, da v pokrajini posamezni ljudje ali skupine ljudi (elite) dejavno in na različne načine oblikujejo ter krepijo regionalno zavest. Nameni teh ljudi so različni, od kulturnih, gospodarskih, do političnih interesov. Družbeno zavedanje postane tudi regionalno zavedanje, na katerem se odraža moč različnih interesov in ideologij. Komunikacije pa so tisto sredstvo, ki omogočajo obvladovanje ljudi oziroma oblikovanje njihove zavesti.

Paasi pri razlagi svojih predstav o regiji izpostavlja naslednje vsebinske sklope: kraj, oblikovanje regij, identiteto.

Kraj, ki je po znanem teoretiku prostora Tuanu strukturiran prostor oziroma lokalnost (locality), ki ima pomen za osebo ali skupino oseb, Paasi opredeljuje z življenjskim, izkustvenim prostorom posameznika (life-space, Lebensraum, éspace vécu). Ta prostor se začenja $\mathrm{z}$ rojstvom otroka in s smrtjo posameznika izgine. Na enostaven način povedana razlika med krajem in regijo je $\mathrm{v}$ tem, da je na kraj osredotočen posameznik, medtem ko se regija razlaga kot kategorija $\mathrm{z}$ izrecno kolektivno razsežnostjo, ki predstavlja delovanje ustanov in zgodovino regije (ne zgodovine posameznika).

Oblikovanje regije, ki naj bi (teoretično) na končni stopnji dosegla institucionaliziran položaj, naj bi po Paasiju potekalo prek štirih stopenj:

- $\quad$ privzemanje teritorialne oblike,

- razvoj konceptualne (simbolne) oblike,

- razvoj ustanov,

- $\quad$ vključitev regije v širši regionalni sistem in regionalne zavesti družbe.

Graf 1: Soodvisnostne stopnje institucionaliziranja regij.

Figure 1: The interacting stages of the institutionalization of regions.

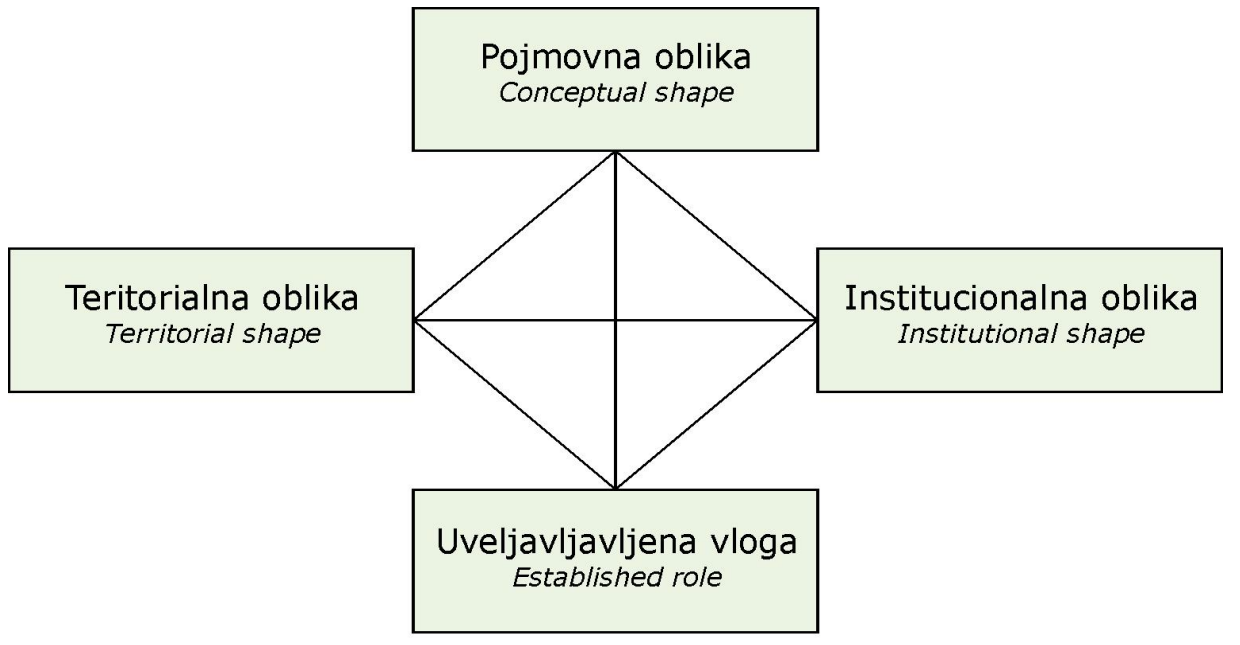

Oblikovanje: Andrej Herakovič

Vir/Source: Paasi, A., 1986. 
Obstoj določene vrste meje je temeljni pogoj za to, da se pojavi občutek zavedanja med prebivalci. Pri tem imajo odločilno vlogo odnosi moči v družbi, ki se izražajo v političnih, upravnih in gospodarskih ustanovah ter v ustanovah simbolnega značaja.

Sčasoma se oblikujejo prostorski (teritorialni) simboli, med katerimi je posebno pomembno ime regije.

Razvoj ustanov je tesno povezan z uveljavljanjem imena regije in drugimi simbolnimi znaki regije. Ustanove krepijo in vzdržujejo podobo regije in identiteto med prebivalci. Razvoj ustanov se ne nanaša le na tiste, ki imajo formalni značaj, ampak tudi na različne regionalne (lokalne) prakse.

Institucionalizacija regije je dosežena, ko regija dobi svoj položaj kot del regionalne delitve družbe in utrjeno vlogo $\mathrm{v}$ regionalnem zavedanju ter postane institucionaliziran del reprodukcije in preobrazbe družbe. Pri tem je pomembna pridobitev upravne vloge regije, še mnogo pomembnejše pa so družbene ustanove, ki odločajo o dejanski moči regije. Zadnja stopnja daje regiji identiteto, ki ne vključuje le materialne osnove, ampak tudi podobe. Navedene razvojne stopnje naj bi bile teoretičnega značaja; nekatere regije se oblikujejo po drugačnem zaporedju razvojnih stopenj, pri drugih so nekatere stopnje malo opazne, pri tretjih pa razvoj lahko zastane na pol poti.

Regionalna identiteta je pojem, ki je z vidika bistva regije ključnega pomena, saj povezuje objektivne/materialne (narava, kultura, gospodarstvo) in subjektivne (posamične in kolektivne predstave) razsežnosti regije. Pri tem Paasi razlikuje med identiteto regije in regionalno identiteto njenih prebivalcev; slednjo običajno imenuje tudi kot regionalno zavedanje (občutenje prebivalcev domače regije). Identiteto regije pa delimo na dva dela: na subjektivno in objektivno. Prva se nanaša na podobo s strani domačih prebivalcev, druga pa na predstave prebivalcev, ki živijo izven regije. Zunanja podoba regije je njen "poster". Notranja podoba regije vsebuje idejo razlikovanja domačega prebivalstva in drugih potez regije od prebivalcev in drugih znakov ostalih regij. Izpostavlja se: "naš" za razliko od "vaš" oziroma "mi" in "oni".

V globaliziranem svetu pa očitno ne moremo vsake identitete pripoznati tudi za regijo, če želimo ostati na geografskih tleh. Paasi $(2002$, str. 139) trdi, da je identiteta v osnovi oblika kategorizacije, kjer se meje uporabljajo za razlikovanje enega območja družbene kolektivnosti od drugega. V sodobnosti, ki jo označuje vse bolj zapletena mrežna organizacija življenja in s tem vse bolj zapleteni procesi preoblikovanja zemeljskega površja, je od posamične do regionalne identitete lahko še dolga pot. To še posebno velja za socialne mreže, v katerih prihaja do različnih stopenj in oblik identitete. Ker pa so družbeni dejavniki odločilni za preobrazbo pokrajine, je razumljivo, da geografi regijo razumejo predvsem kot družbeni konstrukt in historično odvijajoč proces. Če ne drugje, moramo pri historičnosti nujno upoštevati naravno okolje in s tem ohraniti geografsko vsebino regije.

Za celovitejši vpogled $\mathrm{v}$ vsebino regionalne identitete navajamo tri pomembne elemente, ki jih izpostavlja Keating (1998, str. 86):

- spoznavnega: ljudje se morajo zavedati regije in njenih meja, da se ločijo od drugih regij;

- čustvenega: ljudje (ob)čutijo regijo, ki jim zagotavlja okvir za skupno identiteto;

- instrumentalnega: stanje, ko je regija uporabljena kot osnova za mobilizacijo in kolektivno akcijo pri uresničevanju družbenih, gospodarskih ali političnih ciljev. 
Graf 2: Nekatere razsežnosti regionalne identitete.

Figure 2: Some dimensions of regional identity.

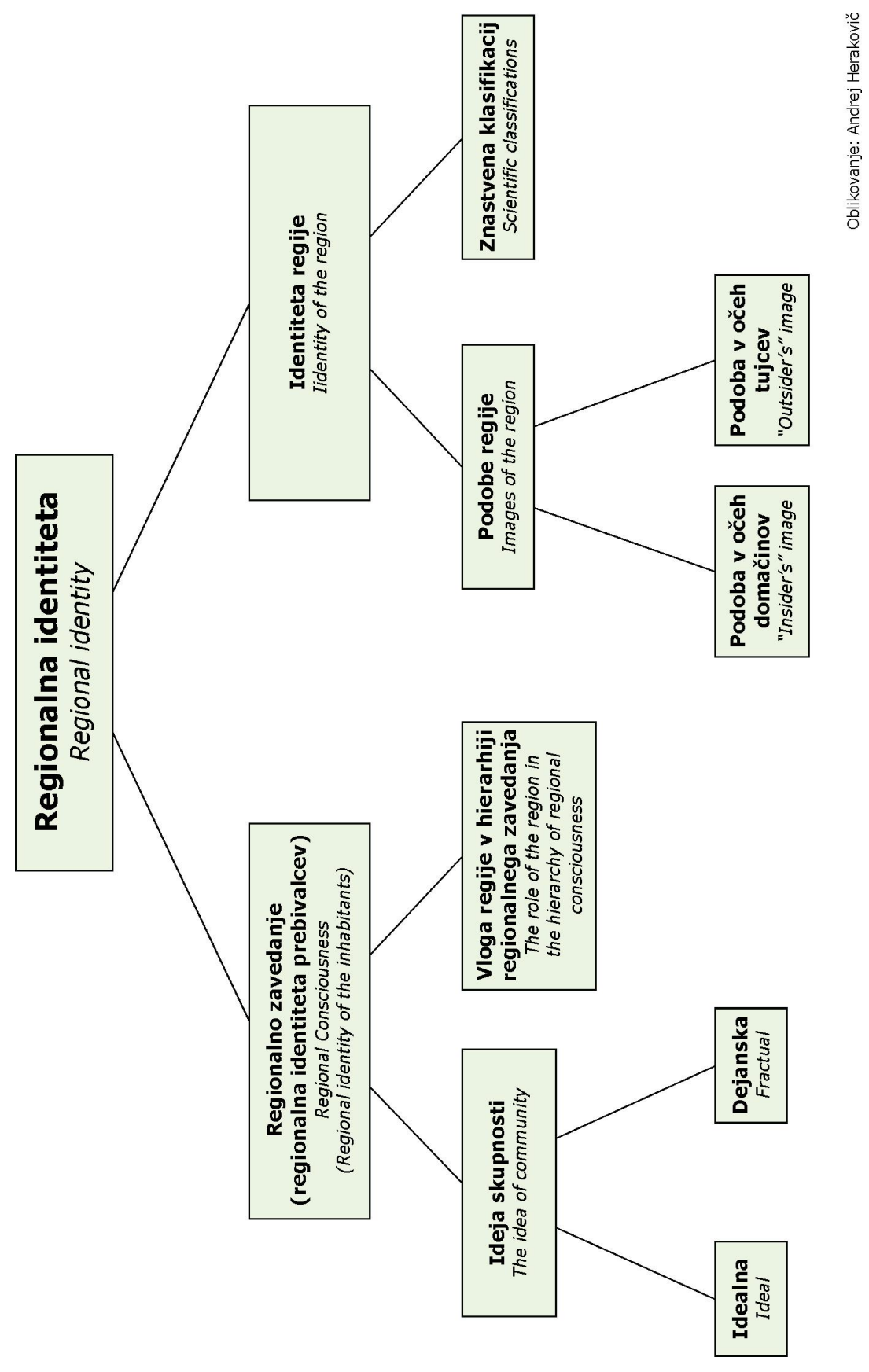

Vir/Source: Paasi, A., 1986. 
V strokovni literaturi se pogosto ponavlja, podobno je tudi pri Keatingu, da je vsaka regionalna identiteta orodje za uresničevanje ciljev nosilnih dejavnikov (nosilcev moči/odločanja) razvoja regije. Pri oblikovanju identitete pa naj bi istočasno potekali trije procesi, ki se izražajo v:

- teritorialnosti (pojavljanje meje pri različnih družbenih dejavnostih, ki ločijo regijo in identiteto od sosednjih),

- simbolnosti (ime regije in številni drugi simboli, ki se odražajo v gospodarstvu, kulturi, $\mathrm{v}$ medijih in pri oblasti),

- institucionalnosti (ustanove, ki vzdržujejo simbolne oblike in hkrati razlikovanje med regijami) (Paasi, 2002, str. 140).

Potrebno se nam zdi opozoriti, da je pri identiteti regij potrebno ločevati med njeno vsebino in njeno uporabo. Pri vsebini ugotavljamo naravne, kulturne, gospodarske, prebivalstvene in politične poteze, preko katerih se regija loči od drugih regij. Drugi del vsebine identitete regije pa je povezan $\mathrm{z}$ njenim trženjem $\mathrm{v}$ najširšem pomenu besede, kar je povezano $\mathrm{z}$ nosilci moči in njihovimi interesi.

Razlike v dojemanju vsebine regije med Hartshornom in Paasijem so bistvene in se kažejo v naslednjem:

1. regija je okvir, znotraj katerega so vsi pokrajinski deli (od kamnov do ljudi), kar regionalna geografija običajno poskuša predstaviti na sintetiziran način (Hartshorn);

2. regija kot institucionaliziran konstrukt, ki odraža kolektivno zgodovino območja in "vsrkava" vsakodnevno življenje njenih prebivalcev (Paasi).

Hartshorn obravnava regijo izrazito mehansko (formalno), s poudarkom na fizičnogeografskih elementih in z ostro/jasno opredeljenimi mejami. Nasprotno pa je Paasijev pristop funkcijski z zavedanjem pomena nosilcev moči/odločanja za oblikovanje regije in njene identitete. Regije so dinamične tvorbe, ki nastajajo, živijo in v močno spremenjenih pogojih odmrejo.

\section{REGIJA}

"Nobena dejavnost v geografiji ni bolj običajna kot razlikovanje med regijami na različnih ravneh; noben geografski objekt ni bogatejši ter kompleksnejši, pa tudi bolj nejasen (nedorečen) kot regija." (Dumolard, 1975, str. 93).

S predstavitvijo pogledov Hartshorna in Paasija na regijo smo želeli opozoriti na prave tektonske premike na področju razumevanja regije, do katerih je prišlo v svetovni geografiji v zadnje pol stoletja. Pogleda omenjenih avtorjev pa še zdaleč ne pokrivata široke mavrice mnenj, prepričanj in spoznanj o regiji, zato si oglejmo še nekatere druge, med seboj zelo različne poglede tujih avtorjev na regijo. Zanimivi so tudi zaradi tega, ker kažejo na strokovno zmedo pri obravnavi vsebine regije in regionalne geografije in na pogosto neupoštevanje spoznanj predhodnikov. Tako kar nekaj geografov vztraja na rigidnem (in samozadostnem) značaju "tradicionalne" regionalne geografije, ki jo Ferras (1986, str. 283) opisuje z 
besedami: "Klasična regionalna geografija se ponavlja z nizom kompilacij, tako v obliki učbenikov, sistematičnih enciklopedij, monografij, ki vedno znova odpirajo iste predale, del v serijah, pri katerih le naslov zagotavlja identiteto obravnavanega območja. Med drugimi pristopi se opaža, da so posamezniki vezani na ozke sezname avtorjev, v katerih prepoznavajo svoja izhodišča...".

Omenjena oznaka stanja tradicionalne regionalne geografije ima splošno veljavo. Dvajseto stoletje, posebno pa še njegova druga polovica, je čas, ko so posamezne geografije začele dobivati močnejša nacionalna obeležja. Anglosaksonski avtorji so se intenzivno poglabljali v teoretske in filozofske osnove geografije in zlasti njenih delov, medtem ko so se Francozi ukvarjali predvsem s praktičnimi raziskavami. Šele v 60. letih 20. stoletja so začeli regiji posvečati sistematično pozornost; čez dve desetletji je iz teh prizadevanj nastal vsedržavni regionalnogeografski projekt s kratico RECLUS, ki je izpostavil novo metodo prikazovanja značaja regij: grafično modeliranje.

V nadaljevanju so nanizani pogledi posameznih tujih raziskovalcev na regijo, pri čemer smo se namenoma izognili kakršnikoli sistematizaciji (časovni, problemski, prostorski) predstavljenih avtorjev.

Za izhodišče obravnave regije se nam zdi primerno predstaviti prostorske strukture in predstave, kot jih opredeljuje Bailly (1992, str. 379):

Prostorske strukture

- strukturne osi

- razmerja med osmi

- (razpoznavna) znamenja

- fizične meje

\section{Socialni in kulturni pomeni kraja}

- simbolne koordinate

- kulturne, zgodovinske, simbolne meje

- podobe, simbolne in/ali funkcionalne predstave

- simbolne poteze (znamenja)

- teritorialni obseg (kraji)

Preglednica predstavlja dva vsebinska sklopa. Prvi je materialni svet, ki ga izkušamo vsakodnevno na ulici, cesti, mostu, v naselju itn. V drugem sklopu so nanizani osebni odnosi do materialnega sveta, ki jih pogojujejo zakonitosti kulture, pridobljena spoznanja in osebnostne poteze: prek njih razlagamo svet in mu dajemo smisel. Vsak prostor prebivalci "obložijo" s čustvi in simboli; od tod njegova mentalna vrednost. Geografski prostor torej lahko smatramo kot kraj, kjer ljudje različnih ideologij "nalagajo" svoje predstave, delovanje in interese.

Regionalni pristop presega neposredno in enostavno dojemanje zemeljskega površja in ga zamenja s skonstruiranim pogledom (Claval, 1998, str. 28). Isti avtor navaja Bungea, da se regionalizacija v geografiji ne razlikuje od klasifikacije v katerikoli znanstveni stroki, le da ima prostorski dodatek, ki ga drugje primanjkuje (Claval, 1998, str. 61). Da pa je regija nekaj posebnega, Claval (1997) na hrbtni strani knjige o regionalni geografiji ugotavlja, da je regija kvas za rast občutkov istovetnosti (identitete), ki ne nehajo naraščati, kljub današnjim številnim možnostim za preseljevanje prebivalstva in vidnemu poenotenju sveta.

Regije imajo različne pomene: formalnega, funkcijskega in zaznavnega (Murphy, 1991, str. 22). 
Dziewonski je $\mathrm{v}$ geografsko literaturo poleg analitične in objektivne razlage pomena regije vnesel še operativnega: regija kot orodje za akcijo (cv: Sagan, 2004, str. 143). Ta pogled je bil $\vee 60$. letih 20 . stoletja še inovativen, saj je regija nastopala kot izrazito strokovna kategorija. Danes je položaj obraten: pojem regije je v vsakdanji uporabi predvsem kot instrument poseganja (usmerjanja, manipuliranja) v razvoj zaokroženih območij; v takšnem pomenu se (pre)pogosto uporablja tudi $\mathrm{v}$ znanstvenih krogih.

Pinchemela (1992, str. 396) jasno ločujeta dve (obe) vsebini regij. Prve so dane regije, "izid igre geografskih učinkov številnih dejavnikov". Neenaka moč prisotnosti pojavov potegne za seboj razlike v zgoščevanju, kar izhaja iz specializacije. Tako se oblikujejo klimatske, kmetijske, industrijske, etnične itn. regije. Človek jih opredeli preko opazovanja njihovih značilnih elementov. Druge so željene regije, ki izhajajo iz družbenih potreb po urejanju teritorialne strukture, da bi se uveljavila njihova avtoriteta, kolektivno upravljanje, posegi, načrtovanja, urejanja. Avtorja opozarjata, da so razlike med obema vsebinama regij pogosto majhne, kot tudi med postopkoma "členitve zaradi poznavanja" in "členitve zaradi vladanja". Regije so istočasno proizvod, zgradba in rezultat: raziskovalec ugotavlja obstoj regij.

Nastanek (institucionalizacija) regij je družbenoprostorski proces, $v$ katerem se pojavi teritorialna enota kot del prostorske strukture obravnavane družbe; ta enota postane opredeljena in oblikovana na različnih področjih družbenega delovanja in zavedanja. $Z$ regionalno preobrazbo regija lahko razpade. To je družbeni, materialni, pa tudi spoznavni proces in ne more biti skrčen na regionalno identiteto ljudi, ki živijo na nekem območju (Reynolds, 1994, str. 236).

Nejasnost pojma regija naj bi bila, ob različni terminologiji, po Dumolardu (1975), posledica neenotne aksiomatike. Regija naj bi bila sicer enkratna, a primerljiva $\mathrm{z}$ drugimi. Dumolard si prizadeva, da bi za regijo, ki jo opredeljuje kot prostorsko celovitost, strukturirano in kohezirano od tistega trenutka dalje, ko je dominanten pojav dovolj močan, da oblikuje strukturo, določil temeljne poteze, ki bi postale splošen kanon. Regijo naj bi opredeljevalo šest temeljnih potez:

1. realnost na različnih stopnjah,

2. odprt kompleksen sistem,

3. kohezija v prostoru in času,

4. regionalna kohezija,

5. homogenost, heterogenost,

6. prepletanje oblik in dejavnikov.

Z naslednjim korakom je Dumolard pokazal značilnosti regij na različnih ravneh.

$\begin{array}{lll}\text { Merilo/raven } & \text { Prevladujoča dejavnost } & \text { Prevladujoča oblika } \\ \text { mestna četrt } & \text { funkcionalnost } & \text { homogenost } \\ \text { dežela } & \text { kulturna skupnost } & \text { homogenost } \\ \text { vplivno območje } & \text { funkcionalnost } & \text { heterogenost } \\ \text { velika regija } & \text { kulturna skupnost } & \text { heterogenost }\end{array}$


Dobršen del razprav o regiji, posebno v angleški geografski literaturi, izhaja s stališč različnih socialnih teorij. Regija (pokrajina) naj bi bila le (bojno) polje, na katerem se odvijajo socialni procesi, ki izhajajo iz razmerja moči. Zato ni čudno, da se namesto regije uporabljajo tudi izrazi, na primer teritorij (territory), ki naj bi predstavljal območje, na katerem osebe ali ustanove izvajajo določeno stopnjo nadzora (Murphy, 1991, str. 28).

Velika pozornost socialnim procesom v "regijah" je obudila pogled, da je regija le intelektualni koncept, čeprav njeni gradniki realno obstajajo na zemeljskem površju. Kot celote, torej kot regije obstajajo šele takrat, ko jih kot take spoznajo raziskovalci (Wishart, 2004, str. 308).

V zadnjih desetletjih so opazno uveljavljene ideje o regijah kot proizvodu součinkovanj med naddržavnimi ali globalnimi institucionalnimi in ideološkimi dejavniki na eni strani ter med krajevnimi (lokalnimi) dejavnostmi, součinkovanji in razumevanji na drugi strani.

Socialni preobrat $\mathrm{v}$ znanosti je usmeril raziskave na intenzivnost medsebojnih odnosov prebivalstva v regiji, kar po Saganovi (2004, str. 141) pomeni, da se je ontološko razumevanje prostora spremenilo v korist ontološkega razumevanja družbe.

Vsako konkretno študijo moramo postaviti v regionalni okvir. Sodobna teoretična literatura o družbi in prostoru nam govori, da so tako postavljene regije socialni konstrukti. Večina takšnih študij si zastavlja vprašanja glede razvoja v regiji, ne da bi raziskovala naravo in pomen regije, ki je bila izbrana za preučitev. Murphy (1991, str. 24) se s takšnim gledanjem na regijo ne strinja in zahteva, da moramo naravo, obseg in značaj regij v empiričnih raziskavah preučevati kot del koncepcije socialnih procesov, ki se odvijajo $v$ teh regijah. Tak pristop pa zahteva socialno teorijo, $\mathrm{v}$ kateri regionalne razmere ne obravnavamo enostavno kot abstrakcije ali kot a priori prostorske danosti, ampak kot rezultat socialnih procesov, ki odsevajo in oblikujejo ideje o tem, kako je svet organiziran.

Bolj kot v svetu regij živimo v geografskem prostoru, čigar razvoj usmerjajo dejavniki na višji ravni: mednarodni odnosi, finančne in industrijske povezave, organizirane ob oseh, polih in megalopolisih (Bailly, Ferras, 1997, str. 119). Kljub takšnemu skepticizmu do regij v sodobnem svetu pa avtorja očitno soglašata s Clozierom, da regija obvezuje geografe, da se soočajo $\mathrm{z}$ realnostjo in se tako izogibajo meglam špekulacij.

Na koncu obravnave regije si oglejmo še dve alternativni predstavi, ki na svoj način pomenita nezaupnico vsebini regije.

Prvi pojem, ki ga Minshull (1967) povzema po Whittleseyu, je compage in naj bi v nasprotju s teorijo (regija) predstavljal prakso. Obstajali naj bi trije tipi regij: $\mathrm{z}$ eno značilnostjo, z več značilnostmi in regija $\mathrm{z}$ vsemi dejavniki; zadnja je prava regija. Zaradi zahtevnosti obravnave vseh dejavnikov jo je mogoče obdelati le timsko. Whittlesey za praktično obdelavo skrčenega števila dejavnikov v regiji uporablja ime compage. Ob številnih različnih pogledih na regijo nima pomena iskati enoznačne definicije; regija najvišje kategorije naj bi bila preprosto compage. Minshull predstavi temeljne značilnosti regije in compagea.

\section{Tradicionalna regija}

- pomen reliefa kot regionalnega okvira,

- poudarek na območju, obliki, velikosti in položaju, 
- predpostavljanje, da se meje vseh vsebin pokrivajo,

- ustaljen seznam števila in zaporedja vsebin,

- enciklopedičen in zato ne vedno iskriv način obravnave,

- težišče na obravnavi fizičnih dejstev.

\section{Compage}

- pomen glavne, središčne vsebine,

- poudarek na jedru in značaju,

- opredelitev regije z obsegom ene vsebine,

- različno število vsebin, njihovih razvrstitev in poudarkov,

- izbira in predstavitev enote zaradi določenega (javnega) zanimanja,

- $\quad$ v središču obravnave je človek.

Tako kot je svet in njegovi deli enkraten, tako tudi ne more biti le ene opredelitve regije ali ene metode za spoznavanje, razmejitev in opis regije. Ko naravoslovne znanosti vse bolj uvajajo sistematizacijo, predvsem zaradi udobja, geografi ne bi smeli postati sužnji tega sistema, saj bi z geografijo prišli v zastrašujoč položaj. Ne moremo pristati na mehanski pristop, ki ga zahteva računalniška tehnologija (Minshull, 1967, str. 156).

Minshullove poglede na regijo bi lahko postavili za most med tradicionalne in sodobne. Še $\mathrm{v}$ veliki meri vpet $\mathrm{v}$ togost konceptov tradicionalne regionalne geografije in več kot pomanjkljivo teorijo čuti bogastvo zapletenosti regionalne zgradbe, ki je ne zna na zadovoljiv način izpostaviti s starimi orodji, zato izumlja pojem compage kot by-pass polnokrvni regiji.

Drug izraz, ki ga Nir $(1987 ; 1990)$ povzema po Koestlerju iz poznih 60 . let 20. stoletja, je holon. Izraz naj bi predstavljal enoto, ki je na eni strani nekaj končnega, celovitega (holos), na drugi strani pa del nečesa širšega. Holon (regija) naj bi bil entiteta, na eni strani obrnjena vase, na drugi pa (istočasno) obrnjena navzven kot del širše entitete. Nir pa ob regiji izpostavlja še en izraz: cona. Homogena poteza določene vrednosti spremenljivke naj bi se imenovala cona. Razlika med cono in regijo ni le v številu skupnih spremenljivk, ampak v obstoju/odsotnosti součinkovanj, odnosov in procesov med spremenljivkami; razlika je torej kakovostna. Celovita regija naj bi bil del zemeljskega površja, na katerem se prebivalstvo, organizirano v okviru določenih družbenih, političnih ali upravnih meja sooča z naravnimi, družbenimi, političnimi in gospodarskimi izzivi. Kar entiteto dela regijo, je vsota odnosov in medsebojnih povezav med dejavnimi elementi v pokrajini (Nir, 1987, str. 194).

Za celoviteši vpogled v mozaik pogledov na regijo povzemimo Paasijevo (1986) vrednotenje načinov obravnave regije. Glede na ideje o regiji, na katere se geografi stalno opirajo, jih deli na: predznanstvene, geografsko usmerjene in kritične ideje.

Predznanstvene ideje predstavlja pogled na regijo kot na praktično izbiro, kot na dano prostorsko enoto (občina, statistična regija...), ki je potrebna predvsem za zbiranje podatkov in nima posebne konceptualne vloge. Takšen pristop bo uporaben v Evropi regij, ker bo možno zajemanje enotnih/primerljivih podatkov.

Geografsko usmerjene ideje gledajo na regijo kot na objekt (na primer tradicionalna geografija landšaftov) ali pa kot na rezultat raziskav empiričnih elementov s pomočjo for- 
malne ali funkcijske klasifikacije. Pogled se pogosto uporablja za potrditev "geografskega vidika", torej pri razpravah, ali so regije resnične ali zgolj miselne kategorije. Tako opredeljene "regije" so primeri akademskih odnosov moči/znanja (učbeniki, priročniki), ki prek tako oblikovanih regij ustvarja prostorske predstave o svetu, pa tudi usmerja ukrepe (na primer oblasti).

Kritične ideje izhajajo iz družbene prakse, odnosov in razprav. Z uveljavljanjem teh idej se je prostorski vidik kot upoštevanja vreden dejavnik vključil v širšo mrežo kulturnih, političnih in gospodarskih procesov in delitve dela. Večina del, ki se uvršča med novo regionalno geografijo, spada $v$ to skupino. Kritična regionalna geografija naj bi idealno dopolnjevala politično-gospodarske pristope $\mathrm{z}$ vprašanji subjektivnosti in oblikovanja identitete; regija naj bi bila namreč družbeni proizvod. Regijo, njene meje, simbole in ustanove se razlaga kot izraz stalnega boja za uveljavljanje pomenov, povezanih s prostorom, tako predstav, demokracije kot blagostanja (Paasi, 2002a, str. 804).

Kot odgovor na slabo določljive regije v okviru nove regionalne geografije Paasi postavlja zelo konkretne zahteve za priznanje obstoja regije: "Regije so zapletene institucionalne strukture (institucionalizirana dejstva), ker slonijo na družbenem dogovoru in ustanovah, kot so mediji, izobraževalni sistem, politične organizacije, oblast in gospodarstvo; večina od njih deluje prek ravni regije. Oblikovanje regije vedno vključuje normativne sestavine, ker so institucionalne strukture strukture pravil, moči in verovanj, znotraj katerih se skozi materialno prakso pojavljajo simboli in ustanove. Ko so le-te oblikovane, so tudi družbeno dejstvo, ker lahko začenjajo delovati, dokler ljudje verjamejo vanje in kolikor časa imajo vlogo v javnem prostoru ali pri oblasteh. To delovanje v okviru regije je lahko istočasno reprodukcija, vzdrževanje stanja in preobražanje (Paasi, 2002a, str. 806).

Če na koncu pregleda razumevanj vsebine regije skušamo postavimo jasno in enoznačno opredelitev, smo v veliki zadregi. Primerneje se nam zdi izpostaviti najpomembejše elemente, po katerih lahko zaznamo zametke ali celo zrelost regije. Za izhodišče lahko vzamemo Dumolardovih šest kriterijev za regijo (1975), predvsem pa elemente, kot jih je opredelil Paasi $(1986 ; 2002 a)$ :

- regija je zgodovinski proces z začetkom in koncem,

- $\quad$ regija je institucionalizirana struktura, ki jo oblikujejo razmerja moči,

- $\quad$ ključne ustanove so lahko v ali pa zunaj regije,

- regija je proizvod delitve dela,

- meje regij so lahko jasne (na primer upravne), ali pa nejasne,

- regije izražajo osebne zgodovine prebivalcev.

\section{NOVA REGIONALNA GEOGRAFIJA}

"Regionalni geografi morajo sodelovati v preobrazbi za boljši svet." (Le Berreu, cv. Gilbert, 1988, str. 222)

Gornji citat, ki ga je po Le Berreu povzela Gilbertova, dobro označuje usmerjenost "nove regionalne geografije". Izpostavljanje "nove regionalne geografije" od srede 70. let 20. stoletja 
dalje je v svetovni geografski literaturi vzbudilo veliko zanimanje. Razlogov za to je več. $\mathrm{Ob}$ prvih korakih renesanse regionalne geografije, ki je skušala (re)definirati temeljne pojme $\mathrm{v}$ regionalni geografiji (obseg/raven, prostor, kraj, lokalnost, regija), so se nenadoma pojavili pogledi, ki so obljubljali regionalnogeografski eldorado. Novost je vzbudila veliko zanimanje, ki mu je sledilo temeljito kritično pretresanje izhodišč novih pogledov na regionalno geografijo. Prvi vtis je, da se je marsikateri novodobni regionalni geograf vsaj deloma "okužil" z novimi idejami, posebno ker so odziv na sodobne družbenogospodarske in politične razmere.

Zagovorniki nove regionalne geografije $\mathrm{v}$ samopredstavitvi predvsem zanikujejo kakršnokoli povezavo s tradicionalno regionalno geografijo, ki je izolacionistična, opisna, statična, nazadnjaška in teoretično bankrotirana; regijo naj bi obravnavala pasivno kot "vsebovalca pojavov" in študij prostorskih razlik naj bi bil njen doseg.

V kritičnem pretresu nove regionalne geografije Holmen (1995, str. 47) navaja njene kratke oznake, kot so jih izrekli nekateri geografi in so zanimivi tudi za nas. Taylor pravi, da je regionalna geografija preteklost, nasprotno pa znani teoretik geografije Johnston govori o povsem novi vrsti regionalne geografije. Thrift svojo trditev, da je nova regionalna geografija v kratkem času naredila dolgo pot, čez nekaj let zamenja s prepričanjem, da je za dosego nove regionalne geografije potrebna še dolga pot.

Cilj nove regionalne geografije je po Gilbertovi (1988, str. 218) pokazati, kako je posebnost kraja ohranjena in preoblikovana $\mathrm{v}$ okviru splošnih družbenih sprememb. Za dosego omenjenega cilja naj bi se dopolnilno uporabljala oba temeljna znanstvena pristopa: analiza in sinteza. $\mathrm{Z}$ analizo naj bi preučili sestavo gospodarske proizvodnje, dela in kapitala, kulturne vzorce in politične odnose. Kulturni, politični in gospodarski procesi skupaj oblikujejo in strukturirajo specifične regije in le s preučevanjem njihovih medsebojnih odnosov lahko spoznamo regionalne posebnosti. S sintezo pa osvetlimo splet odnosov, ki povezujejo družbene dejavnike, da oblikujejo prostorske razlike. Načelno stališče, da je pri sintezi potrebno upoštevati le pomembne dejavnike, je bilo sprejeto že pri klasičnih regionalnih geografih (Hartshorne, Sauer, Vidal de la Blache), vendar le redko doseženo, zato dobro poznane kritike o širokem opisovanju v tradicionalnih regionalnogeografskih delih. Po novih pogledih naj bi regionalna analiza morala omogočiti razlago regije kot proizvoda medsebojne povezanosti različnih prostorskih ravni.

Nov pristop spreminja odnos do preteklega razvoja oziroma do zgodovine. Zanimanje klasičnih geografov, kot trdi Gilbertova, je bilo usmerjeno predvsem v ugotavljanje, kako se spreminjajo vsebine območij s prehajanjem ene kulturne oblike v drugo. Geografija kot genetična veda je razlagala zaporedje dogodkov, skozi katere so bile zgodnejše pokrajine preobražene $\mathrm{v}$ kasnejše. To je potekalo s preučevanjem odnosov med ljudmi in naravo, čemur lahko rečemo zgodovinski razvoj. Analiza je vsebovala pregled materialne kulture regije kot odtis odnosov med naravo in družbo v različnih obdobjih. Sodobna regionalna geografija po mnenju Gilbertove zavrača ta genetski pristop. Sedanje regionalne strukture naj ne bi bile prilagoditve predhodnih; torej niso zvezne s preteklostjo, ampak v stalnem prilagajanju. Kljub vsemu je zgodovina neobhodno metodološko orodje za regionalne raziskave (Gilbert, 1988, str. 220). Z regionalno analizo naj bi preučili mehanizme družbenega součinkovanja, ki vztrajajo $\mathrm{v}$ toku časa ter spremembe socialnih razmer, ki lahko pripeljejo 
do različnih regionalnih razlik. V pokrajini naj bi šlo za serijo prekrivajočih se zgodovin, ki se istočasno pojavljajo $\mathrm{v}$ regiji in so $\mathrm{v}$ njej medsebojno povezane. Neposredna časovna veriga je zamenjana s posredno, v ospredje pa se postavljajo recipročni odnosi. Najbrž je nekoliko tendenciozno gledanje zagovornikov nove regionalne geografije, da se je tradicionalna regionalna geografija ukvarjala predvsem s preteklostjo; za sodobno trdijo, da je znanost sedanjosti, pa tudi prihodnosti. Še več, regionalne analize se odpirajo političnemu delovanju. Kot že navaja citat pod naslovom: regionalna geografija ni več le orodje za poznavanje sveta, ampak tudi orodje za delovanje v praksi.

Nova regionalna geografija izhaja iz različnih miselnih in teoretskih podlag in ne pomeni nekaj enoznačnega. Za razlago regionalnih potez raziskovalci iščejo pomoč pri socioloških in ekonomskih teorijah. Temeljne smeri družbene geografije, ki se uveljavljajo v novi regionalni geografiji, naj bi bile po Brandshawu naslednje (Holmen, 1995, str. 48):

- za humaniste je regija vir identifikacije in pomena;

- za strukturaliste in teoretike svetovnega sistema je regionalna sprememba odgovor na svetovne kapitalistične procese;

- za zagovornike Hägerstrandove časovne geografije in Giddensove strukturalistične teorije je regija arena za družbene interakcije;

- za "realiste" so lokalne različnosti posledica negotovih prostorskih učinkov gospodarske prenove.

Podobno Gilbertova (1988, str. 209) opredeljuje glavne smeri nove regionalne geografije:

- regija kot žarišče identifikacije (specifičen niz kulturnih odnosov med skupino ljudi in posameznimi kraji);

- regija kot medij za družbene interakcije (izpostavljanje aktivnosti družbenih odnosov vodi k političnemu pogledu na regijo);

- regija kot lokalni odgovor na kapitalistične procese.

Po mnenju Gilbertove naj bi bila zadnja opredelitev regije najprimernejša za sodobno geografijo. Tudi iz tega lahko uvidimo, da nova regionalna geografija naj ne bi bila toliko orodje za spoznavanje sveta kot pa orodje za konkretno delovanje. Iz nove regionalne geografije pogosto veje radikalizem.

V nasprotju s preteklostjo je današnja pokrajina podvržena hitrim spremembam, ki so na različne načine posledica delovanja svetovnega gospodarstva; vsi deli sveta so usodno (so)odvisni. To dejstvo je "nove regionaliste" tako prevzelo, da pozabljajo na fizično okolje. Srednja pot med tradicionalno in "novo" regionalno geografijo bi bila po mnenju Holmena (1995, str. 51) primernejša za bodoče spoznavanje lokalnih in globalnih sprememb. Isti avtor izpostavlja poltradicionalno (semi-traditional) geografijo, ki naj bi preučevala "pogoje živjenja v regionalnem okviru", za kar pa je potrebno upoštevati družbene in naravne dejavnike.

Čeprav je za novo regionalno geografijo značilen prenovljen poudarek na kraju in regiji, se zdi, da je drugi pojem nekako v nemilosti. Ni jasno, ali je vzrok v teoretski nedoslednosti, ali v zapletenosti/prepletenosti socialnih in ekonomskih struktur in procesov, ki ne dajejo trdne opore za jasno opredelitev regij. Zato so od regije pogostejši izrazi kraj, lokalnost, teritorialnost. Kraj in regija naj bi imela različne pomene kot posledico vpliva okolja, 
različnih jezikov, kultur, zgodovine. Na razumevanje vsebine obeh pojmov pomembno vpliva njun položaj med družbenimi in naravoslovnimi vedami v konkretnem okolju. Paasi (2002a, str. 803) je stanje na posrečen način opisal s kratkim stavkom: "regionalne besede" torej vedno odražajo regionalne svetove. Ali drugače: v vsakem okolju se oblikujejo svojstvene predstave o regiji.

Zagovorniki nove regionalne geografije $\mathrm{v}$ nasprotju s tradicionalno geografijo, ki je izpostavljala odnose med naravo in družbo, zagovarjajo pomen socialne teorije za razumevanje regionalnega razvoja. Iz nove regionalne geografije se je "izgubilo" naravno okolje. Kraj in regija sta pogosto obravnavana le kot "kraj srečevanja". Potrebna je, z besedami Ilešiča, nova reintegracija regionalne geografije. Holmen ugotavlja (1995, str. 58), da sta pojma bližina in prostor zamenjana s pojmoma podobnost in misel. To pa pomeni, da se je regionalna geografija kot "fizična znanost" spremenila v "logično znanost", kar je temeljni prelom s sedanjo regionalno/geografsko epistemologijo. Razumevanje družbe je v najbolj razvitih zahodnih državah res mogoče razumeti skozi politično ekonomijo, kjer so regionalni procesi odsev lokalnega odziva na (globalno) kapitalistično gospodarstvo; a še tu je tak pristop nezadosten za pojasnjevanje logike regionalnega razvoja, zato bi ga bilo primerneje označiti kot obujanje zapoznelih teorij odvisnosti in svetovnega sistema. Po Holmenu se je radikalna nova regionalna geografija ujela $\mathrm{v}$ isto past kot prostorske vede: svet vidi kot enovzročnega in predpostavlja, da so temeljna načela prostorske organizacije povsod ista. $\mathrm{V}$ dobro pa je novi regionalni geografiji treba priznati njeno prizadevanje za razvoj teorije $\mathrm{v}$ nasprotju z dobršnim delom tradicionalne regionalne geografije, ki pokrajino najprej opisuje, nato pa skuša najti smisel. Pri tem je veliko tveganje, da vidimo to, kar želimo videti in da delamo tako, kot smo navajeni. Pomanjkanje teorije je torej napaka tradicionalne regionalne geografije. Tu pa je vredno prisluhniti Holmenovemu opozorilu, da problem ni $\mathrm{v}$ teoriji, ampak v načinu njene uporabe. Vsako resno razumevanje kateregakoli kraja mora nujno poseči v preteklost, ob tem pa ohraniti širok pogled in postaviti raziskovani objekt $\mathrm{v}$ širok okvir (Holmen, 1995, str. 60).

\section{Z REGIJO TESNO POVEZANI POJMI}

Teorij do zdaj nebroj

porabnik sem ponosen bil;

pozdravil vsako novo,

preklinjal staro.

Zato sem končno se obrnil-

s paradigem legijo obdan-

se $k$ Hartshornu znova vrnil,

$z$ regijo navdan.

Emrys Jones (cv: Nir, 1987, str. 187). Prevedel in prepesnil Marijan M. Klemenčič.

Ker do regije kot izrazito celovitega in zapletenega pojava prihajamo postopoma prek opredelitve predhodnih, enostavnejših pojmov, si na kratko oglejmo nekatere. 


\section{Geografski (prostorski) obseg, raven/stopnja}

Geografski pojem, tesno povezan z vsebino regije, v teoretičnem pogledu v slovenski geografiji skoraj neznan, čeprav je prisoten v vsaki geografski raziskavi, je skala. V slovenščini bi angleškemu izrazu scale težko našli vsebinsko enoznačen pomen. V podnaslovu je zato navedenih več izrazov: obseg (predstavlja površino), raven, stopnja (prostorska hierarhija obsega območij). Podobne težave imajo Francozi, ki izraz prevajajo z niveau géographique in échelle spatiale (Encyclopédie de géographie, 1992). V razpravi bomo uporabljali več izrazov glede na vsebinske zveze: obseg, prostorski/geografski obseg, raven/stopnja. To se nam zdi povsem upravičeno zaradi tega, ker ima pojem horizontalno in vertikalno razsežnost. Družbeno, politično in gospodarsko življenje ter inštitucije so organizirane istočasno ploskovno (horizontalno) in hierarhično (vertikalno).

Geografski obseg/raven opozarja na funkcijsko prilagajanje merila dejanskim razmeram v pokrajini; primer: niz hierarhično nanizanih funkcijskih enot, od homogenih korem do heterogene svetovne ravni. Najnovejše razumevanje obsega, posebno v okviru nove regionalne geografije, se omejuje predvsem na socialno-ekonomske dejavnike, pri katerih ga zanimajo zlasti povezave. Prostorski obseg/raven določuje vsebinski in metodološki značaj raziskav, z druge strani pa raziskovana problematika določuje obseg preučevanega območja. To je še posebno očitno pri analizi strukturnih odnosov, omrežij, součinkovanj. Prostorske ravni lahko razumemo kot rezultat moči odnosov na različnih področjih, ki jih opažamo v sodobnem, z globalizacijo označenem svetu, kar je z enostavnim modelom zelo nazorno prikazala Straussfoglova (1997). Iz navedenega lahko zlahka razberemo, da je obseg/raven ključnega (izhodiščnega) pomena za preučevanje in razumevanje vsebine regij.

Po mnenju Paasija (2004, str. 536) je pojem skale bolj očitno kot katerikoli drug pojem vstopil v geografske razprave v 80. letih 20. stoletja. Geografi so ga dodali takšnim ključnim izrazom, kot so regija, kraj, prostor. Pojem obsega je v geografskih raziskavah prisoten od začetka, posebno še pri uporabi "regionalne metode", to je pri klasificiranju in kartiranju. Pogosto so geografi določevali prostorske obsege preučevanih območij ali pojavov ad hoc, ali pa so se (družbeni geografi) naslanjali na upravne enote (občine, okraje, države itn.). Formalno/arbitrarno določevanje obsega grobo posega v pokrajinsko strukturo in "ločuje nedeljivo in/ali povezuje nepovezano in nebistveno ter tako zmaliči zgradbo in obliko" (Paasi, 2004, str. 537). Zlasti v sodobnem svetu, ko številni objekti (razvojni dejavniki) niso očitno materializirani in delujejo na različnih ravneh in na različnih območjih (inštitucije in njihovi načini delovanja), je upoštevanje obsega/ravni ključnega pomena za učinkovito preučevanje stanja in sprememb v pokrajini. Ker se pozornost precejšnjega števila geografov odvrača od preučevanja fizične strukture pokrajine k njenim (notranjim) procesom, je razumljivo gledanje nekaterih geografov, ki k obsegu/ravni pristopajo kot dogodku, procesu, součinkovanju. Taylor (1982) razlikuje različno stopnjo "materializiranosti" območja glede na obseg (hierarhično stopnjo) preučevanega območja: globalna "dejanska", državna "ideološka" in lokalna "izkustvena" raven. Brenner (2001) govori o dvojnem pomenu obsega. Enoznačni pomen se nanaša na oblikovanje določenega vidika družbeno-prostorske organizacije znotraj sorazmerno jasno razmejenega geografskega območja (lokalnega, mestnega, regionalnega, državnega). Poudarjena je geografska enota, ki je znotraj 
sebe sorazmerno močno diferencirana, hkrati pa zaključena. Obseg je v tem primeru usmerjen na mejo, razmejitev, postopek določevanja obsega pa na postopek razmejevanja. Večpomenskost obsega pa se nanaša na oblikovanje razlik in na urejanje hierarhije med obsegi (območji); to pomeni oblikovanje prostorskih enot in razlikovanje med njimi ter njihovo umeščanje v sistem manjših/večjih enot. Obsegi so po Brennerju pomembni kot načini hierarhizacije: družbeno-prostorsko razlikovanje se namreč materializira prek obsegov.

Graf 3: Strukturni model hierarhičnih povezav v sodobnem svetovnem gospodarstvu.

Figure 3: A structural model of the hierarchical linkages in the modern world-economy.

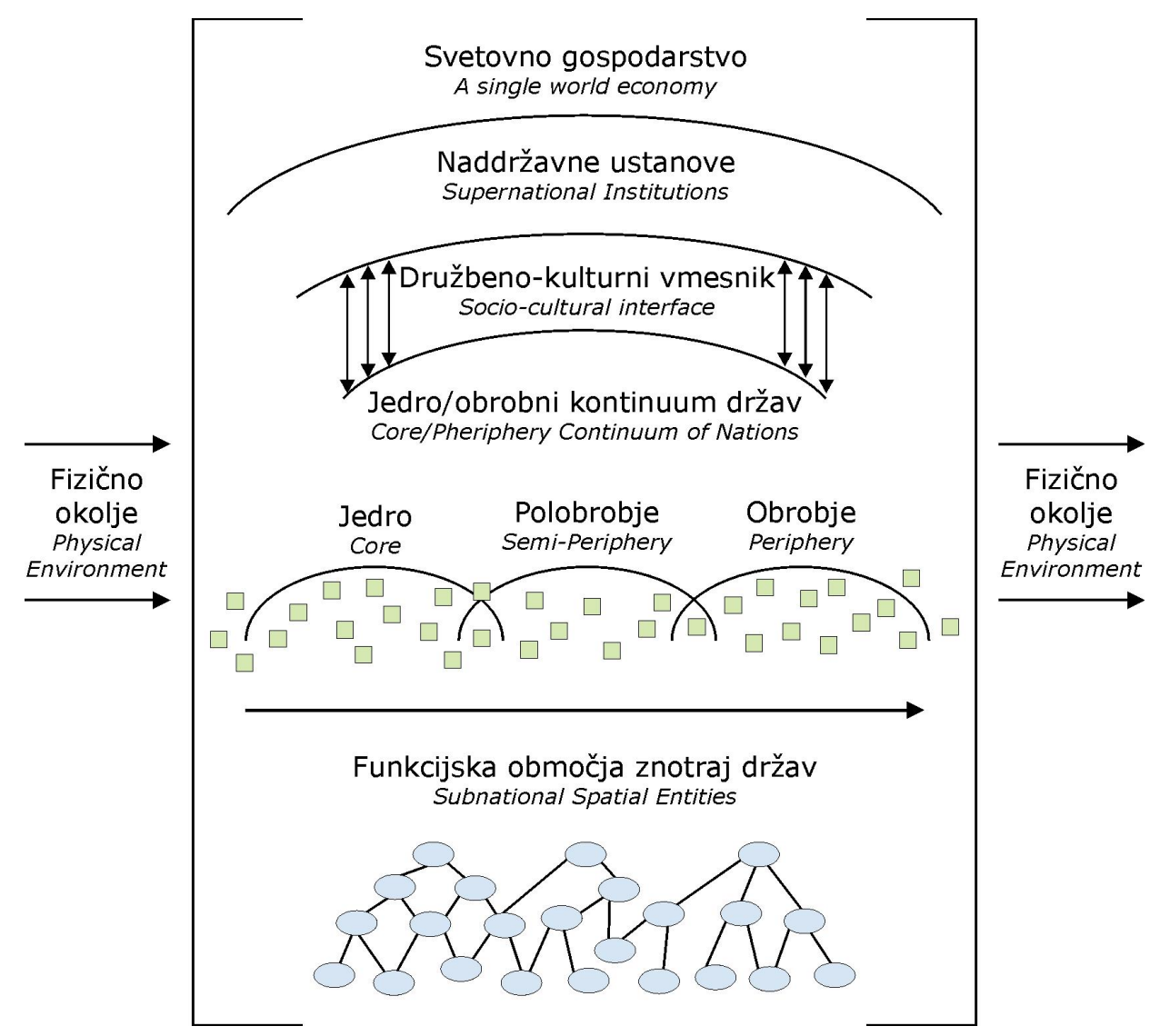

Vir/Source: Straussfogel, D., 1997.

V razpravah o prostorskih stopnjah sta se izoblikovala dva pogleda na njihovo uporabo: prvi je praktični pristop, po katerem bi morali vsebino pojma in njegovo naravo razkrivati s praktičnimi raziskavami, drugi pristop pa bi lahko imenovali teoretičnega; tako Jones (1998) predlaga, da bi na obseg gledali kot na epistemologijo, na način spoznavanja sveta. 
Kakšna je povezava med obsegom in regijo? Če sprejmemo poglede Paasija (2004, str. 540), je nastanek regije trenutek v regionalni preobrazbi družbene prakse in družbenega zavedanja, do katerega pride na različnih prostorskih ravneh in znotraj različnih časovnih obdobij. Tako sta regija in prostorski obseg dve plati procesov prostorskega razlikovanja, a ne nujno ista stvar. Prostorski obsegi niso trajno določeni, a so strukturirani in institucionalizirani na zapleten način z dejavnostmi, ki oblikujejo in preoblikujejo geografske prostore, ki so lahko konkretni, močni in jasno razmejeni, ali pa na zunaj slabo razpoznavni ali celo nevidni.

\section{Kraj}

Kraj (angl. place) kot območje delovanja dobiva vse večji strokovni pomen, posebno še z nesporazumi glede vsebine regije; je pojem, ki je v sodobni geografiji primeren za največ namenov med ključnimi besedami. Paasiju je kraj prostorsko-časovni gradnik regije. Če regije smatramo za multiskalarne institucionalizirane strukture, so kraji kumulativni arhivi osebnih prostorskih izkušenj. Kraj torej ni povezan z nobeno specifično lokacijo. Uporablja se za bolj široka obzorja (odprtost, počasni prehodi) in za različno velik obseg. V sodobnem času je to lahko razumljivo, saj ljudje pogosto menjajo kraj (stalnega ali začasnega) bivanja.

Kraj vedno nakazuje njegovo občutenje, četudi izkušnja ni posebno prijetna. Vsebina pojma kraj je zato kakovostno drugačna od pojmov pokrajina ali prostor (Butz; Eyles, 1997, str. 2).

V novi regionalni geografiji se kraj obravnava kot prilagodljiva kategorija za predstavljanje poteka in učinkov globalizacije in novega razčlenjevanja sveta.

Kategorija kraja z njegovo humanistično "prtljago" je začela postajati zamenjava za pojem regije (Paasi, 2003).

\section{Regionalna identiteta}

Ideologija lahko igra ključno vlogo v diskurzu o regionalni identiteti, saj izhaja iz gospodarskih, kulturnih in političnih interesov, to je iz moči. Identiteta, vezana na geografski prostor, je izraz povezanosti človeka/družbe z naravnim okoljem, zato je za geografsko teorijo dragocena. Sodobne obravnave identitete pa nas opozarjajo, da moramo biti pozorni na njihovo vsebino; ne gre za poenotenje vsebine pojma, temveč za prevzem takšne definicije, ki prispeva k razvoju geografske stroke. Tako Claval (1995) opozarja, da se je vsebina regionalne identitete izpraznila, ker je izgubila del avtentične vsebine, ki jo je nadomestila nova, kulturna vsebina. Seveda ne gre iz geografije izganjati novejših razumevanj identitete; potrebno je le jasno ločevati med različnimi opredelitvami in razvijati tiste, ki slonijo na prostorskem konceptu.

Ljudje smo vsak dan v izkustvenem odnosu do okolja v najširšem pomenu besede. Pridobimo si občutek domačnosti, ki se izraža na več načinov, na primer z govorom in občutkom pripadnosti domačemu okolju. Geografska identiteta je hierarhično urejena, od pripadnosti domači vasi do kozmopolitizma (svetovljanstva). Zelo močna je, ne le v Sloveniji, identiteta, vezana na historične pokrajine. 
Z regionalno identiteto se je $\mathrm{v}$ okviru opredelitve regije temeljito ukvarjal Paasi (1986). Opredelil je številne oblike istovetnosti. Izhaja iz spoznanja, da regionalna identiteta ne more biti skrčena le na regionalno zavedanje posameznikov, ki živijo v dani regiji. Koncept je primerneje postaviti na proces institucionalizacije, ki vključuje reprodukcijo regionalnega zavedanja $v$ prebivalcih regije (in ljudi, ki živijo izven regije) in materialnih ter simbolnih potez regije kot delov procesa družbene reprodukcije; oblikovanje družbene identitete in proces družbene reprodukcije je namreč ena in ista stvar. Omenimo naj le še notranje in zunanje podobe regije, ki se lahko med seboj zelo razlikujejo.

Geografsko identiteto moremo/moramo jemati za temeljni kazalec obstoja regije. Zanimiv je pogled arhitekta na prostorsko (regionalno) identiteto, torej pripadnika stroke, ki naj bi znala prisluhniti "pokrajinski stvarnosti", da bi lahko človekovi meri ustrezno plemenitila bivalno okolje."Odnos človeka do prostora je več kot le sposobnost orientacije v neki pokrajini; opravka ima z mnogo globljim razvojem identifikacije, kar pomeni postati prijatelj z določenim okoljem. Človekova identifikacija s prostorom predpostavlja, da imajo območja nek značaj oziroma določene znake, ki ločijo prostor od drugega, nekaj, kar daje prostoru enkratnost...Ne gre za nekakšen okoljski determinizem. Spoznavamo, da je človek sestavni del njegovega okolja...Pripadati nekemu okolju pomeni imeti v njem bivanjsko oporo vsakodnevnega življenja." (Abel, 2000, str. 143). Pogled arhitekta na vsebino in značaj pokrajine je vzpodbuda/očitek geografiji, naj celovitejše gleda na pokrajino in v njej razpoznava posebnosti.

\section{Sistemska teorija in regija}

Kot marsikaj v življenju ne izpolni pričakovanj, tako je tudi s sistemsko teorijo v geografiji. Pristop, ki je izrazito naravnan k preučevanju celovitosti, sestavljene iz niza različnih dejavnikov, naj bi bil prav idealen pripomoček za preučevanje pokrajinske stvarnosti. Na to možnost, posebno z vidika regionalne geografije, je v poznih 80. letih 20. stoletja opozoril M. M. Klemenčič (1987), hkrati pa obžaloval (pre)majhno zanimanje geografske srenje za ponujeno priložnost. Po njegovem mnenju sistemska teorija lahko pripomore $\mathrm{k}$ celovitejšemu preučevanju zemeljskega površja in ustreznejšemu razumevanju regije. Na prvi pogled stanje dve desetletji kasneje ni bistveno bolǰ̌e; formalna uporaba metodologije splošne teorije sistemov je $\mathrm{v}$ geografskih preučevanjih zelo redka, zato pa je $\mathrm{v}$ večji meri čutiti sistemski pristop/miselnost. Sistemski način razmišljanja je v geografiji že star in bi ga celo lahko označili kar za geografskega. Marconis (1996, str. 185) piše o "intuiciji sistemov", ki pa je bila še trdno vpeta $v$ kartezijanski miselni koncept, ki izpostavlja preučevanje linearnih povezav. Sistemski pristop pa presega linearno vzročnost in mehča njeno togost in determinizem.

Sistem, ki po definiciji temelji na dveh osnovnih pojmih: celovitosti (organiziranosti različnih elementov) in součinkovanju (med elementi), je idealno orodje za preučevanje regij, pa naj bodo te dejanske (materializirane), ali pa le mentalni konstrukti. Izhodišče sistemske teorije ni več organizem, ampak informacija, ki omogoča presojo o obstoju organizma. Takšen pogled se v novi regionalni geografiji odraža v močnem poudarjanju pomena pove- 
zav, stikov, odnosov, razmerij na račun materializiranih pokrajinskih oblik. Ob tako gledanje se hitro prilepi želja po uravnavanju/usmerjanju/krmiljenju sistemov/"regij", kar je približevanje kibernetiki in hkrati oddaljevanje od geografskih posebnosti.

Bird (1993) je v temeljitem pregledu dejanskih in možnih teoretsko-metodoloških pristopov sistemske teorije v geografiji previden in zadržan. Iz njegove ocene izhaja, da je za geografijo uporaben predvsem sistemski vidik, ne pa izrecna uporaba metodologije sistemske teorije, ki naj bi bila preveč sofistificirana in zato manj primerna za večkrat nujne vložke subjektivnosti v geografskih preučevanjih. Bird tudi na regijo kot sistem gleda precej zadržano, saj naj bi v taki obliki lahko nastopala le redko, predvsem na makro ravni.

Chapman (1977), ki je v geografiji prvi temeljito predstavil pomen sistemske teorije za geografijo, napada tradicionalno opredeljevanje regij in poljubno razmejevanje prostorskih enot. Ni pa iskal možnosti, da bi s pomočjo sistemske teorije opredelil vsebino "prave" regije. Nasprotno, kot ugotavlja Steiner (1979) v kritiki Chapmanovega dela, je le-ta opredeljeval geografske sisteme, pri čemer je oblikoval pogled na naravo geografskega preučevanja, ki je marsikomu tuja. Geografija naj bi namreč morala dajati prednost študiju pokrajinskih objektov pred prostorskimi enotami. Izpostavlja pomen relativnega prostora kot posledico študija prostorskih struktur sistemov. Geografska istovetnost/identiteta v takšnem pristopu povsem izgubi svoj pomen.

Za Nira (1987, str. 194) sistemski pristop lahko odgovori na nekatere temeljne probleme $v$ geografiji, posebno še v regionalni, saj pripomore k preseganju treh glavnih dihotomij v geografiji: človek - narava, kraj - prostor, lokalnost - globalnost (problem merila/obsega). Bistvo sistemske teorije je $\mathrm{v}$ tem, da k pojavu pristopa kot delu celote; pomen odnosov med sestavinami sistema in njihovim okoljem je utemeljen s procesom. Z izhodom (output) razumemo vso ustvarjalnost in produktivnost regije, pa naj bodo izdelki, duhovne vrednote, ustvarjalnost, vključno s kulturnimi, političnimi ali družbenimi idejami. Izhodov sistema torej ne moremo meriti le z gospodarskimi dosežki. Sistemski pristop pomaga opredeliti in preučiti dinamične, stagnirajoče ali nazadujoče regije. Olajšuje razumevanje, da so spremembe najbolj gotov proces. Pristop je uporaben za načrtovanje razvoja, za politično delovanje, pa tudi za zadoščevanje intelektualni radovednosti.

Po mnenju Vrišerja (1987, str. 130) pa je uporaba sistemske teorije v geografiji do nadaljnjega vprašljiva. Takšna ocena izhaja iz dejstva, da Vrišer pogojuje/enači uporabo sistemske teorije s sodobnimi matematičnimi metodami in računalniško obdelavo, za kar pa naj ne bi bilo dovolj natančno izmerjenih podatkov in temeljito razčiščenih pojmov. Poleg tega za uporabo sistemske teorije naj ne bi bilo razčiščeno teoretično in praktično vprašanje, kako povezati (uskladiti) "deduktivna" oziroma "sintezna" stremljenja sistemske teorije z individualnim značajem vsake preučevane regije. Za razumevanje problema manjka Vrišerjeva razlaga individualnosti regije.

Sistemska teorija (bolje sistemski pristop) nudi orodje ravno za preučevanje kompleksnih struktur, kakršne so (tudi) regije. Če pa je z individualnostjo mišljena tudi enkratnost (regij), pa izstopamo iz okvira znanstvenega dela; posploševanje je namreč temeljna značilnost znanosti. 
Graf 4: Prehod od zaprtega k odprtemu sistemu; primer alpske vasi Obergurgl.

Figure 4: Crossing from the closed to the opensystem; the case of the Alpine village Obergurgl.

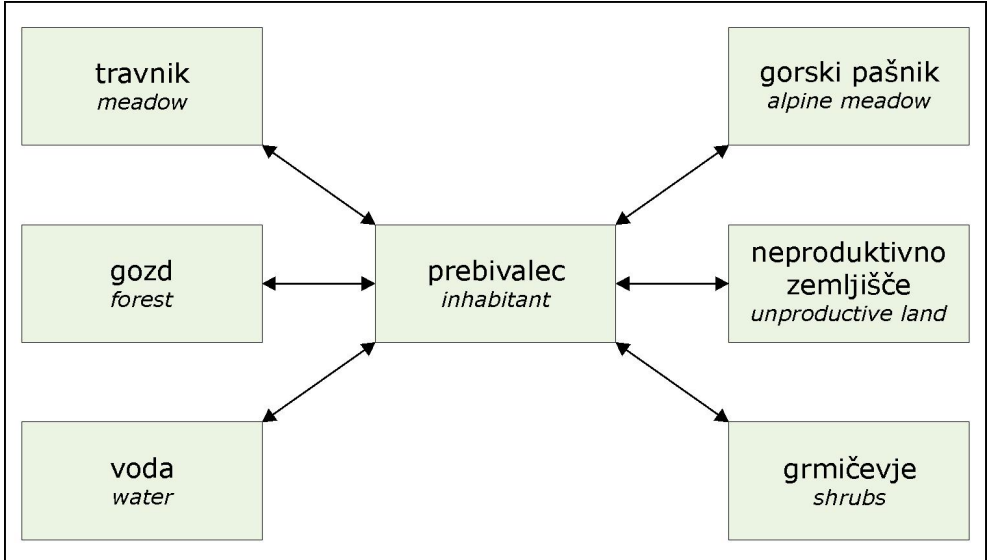

OBERGURGL 1860

zaprt sistem

closed system

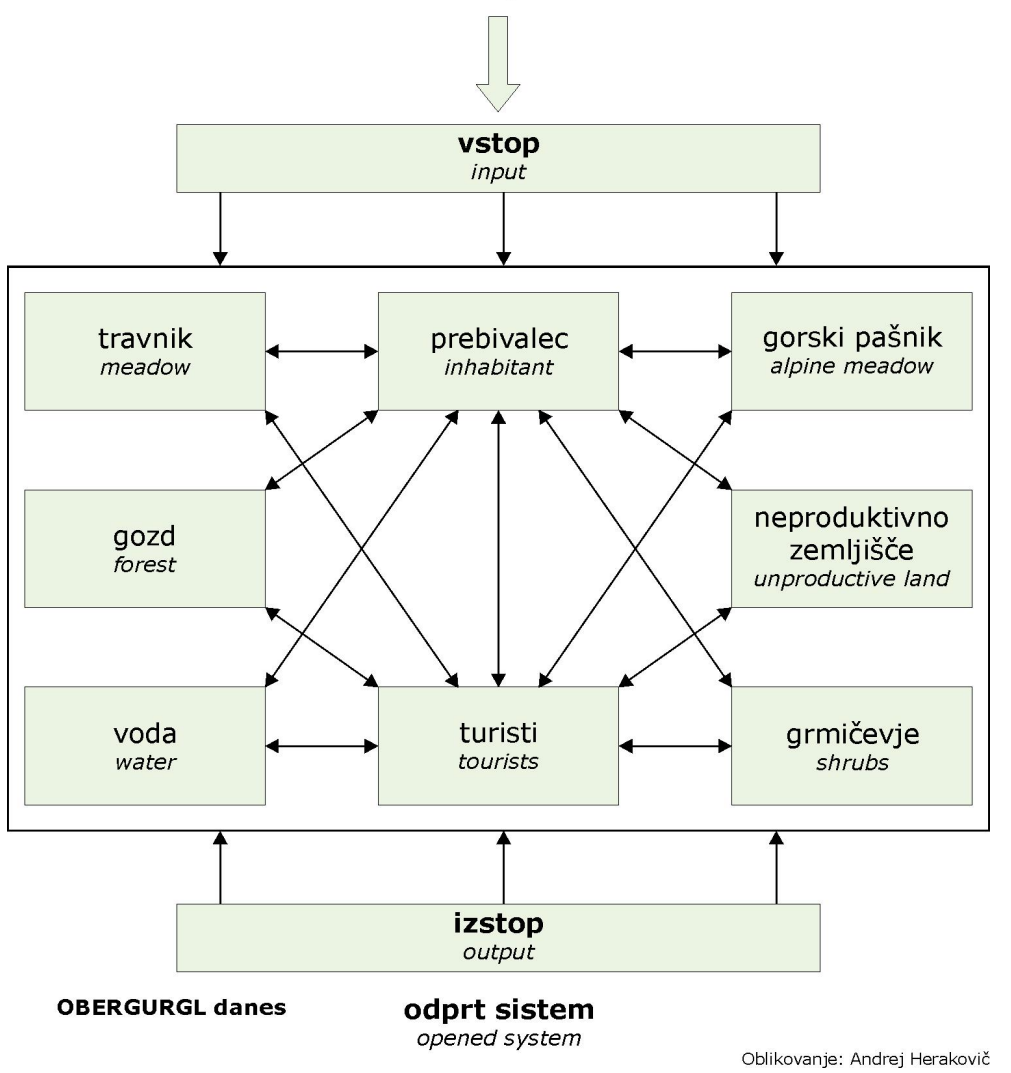

Vir/Source: Moser, W., 1975. 


\section{REGIJA V SLOVENSKI GEOGRAFSKI LITERATURI}

Kot se nobeno resno geografsko preučevanje ne more izogniti pojmu regija, tako se mu ni izognila tudi slovenska geografija. Nasprotno, številni geografi so čutili potrebo in dolžnost, da skušajo opredeliti ta pojem. Še več pa je bilo o regiji povedanega posredno, prek obravnavanja regionalizacij, ki so med slovenskimi geografi vedno vzbudila veliko zanimanje in živahne odmeve. S tem v zvezi omenimo le posvet o teoriji in metodologiji regionalne geografije leta 1987 v Ljubljani.

Najbolj intenzivno se je s problemom regije (in regionalizacije) ukvarjal Ilešič. Njegova prizadevanja so šla v korak z njegovimi prizadevanji za reintegracijo geografije, torej za celovitim obravnavanjem zemeljskega površja v nasprotju s tedaj vse bolj izrazito delitvijo geografije na posamezne veje. Večina njegovih tovrstnih prispevkov je objavljena v temeljnem teoretskem delu slovenske geografije: Pogledi na geografijo (1979).

Da bi bila slika stanja na področju razumevanja (predstav) vsebine regije v slovenski geografiji čim bolj verodostojna, bomo navedli nekatere definicije regije, ki so pogosteje uporabljene/izražene.

Primerno je, da pregled začnemo z definicijo regije, kot je podana v najbolj uporabljenem geografskem delu: Uvodu v geografijo: "Regija je del zemeljske površinske sfere (pokrajinske prostorske stvarnosti ali geografskega okolja), pri katerem se pojavi in faktorji ter delujoče sile medsebojno povezujejo v kompleksno in individualizirano celoto." (Vrišer, 2002, str. 22). V nadaljnji razlagi Vrišer poudarja pomen dosedanjega razvoja, notranjih kvalitetnih razlik in medsebojne povezanosti/součinkovanja med posameznimi sestavinami geografskega okolja. Na ta način naj bi se takšna enota razlikovala od drugih. $\mathrm{Z}$ drugimi besedami, gre za območje, ki ima svojstveno organizacijo prostora, nastalo v določenem časovnem obdobju. (Površni) bralci definicije zanemarijo njeno bistvo (individualiziranost) in v nji najdejo le (katerekoli) razlike med območji. Med takšne zagovornike regije bi lahko uvrstili že omenjenega Vrišerja, ki v nasprotju s splošno definicijo regije, podano v učbeniku, ponuja svoje razumevanje vsebine regije: "Regija je pokrajina, območje, predel ali ozemlje, ki ga družijo podobne ali celo enake naravne in/ali družbene značilnosti. Ločimo naravnogeografske ali fiziognomske, homogene, funkcijske (nodalne) ali polarizirane regije." (Vrišer, 1999, str. 38). V Enciklopediji Slovenije (1996) Vrišer meni, da se z regijo lahko označuje območje, svet (alpski), višinski pas (subalpski pas), provinca (upravnopolitična, floristična), predel (aridni), rajon (vinogradniški), prostor (poselitveni), okoliš (šolski), pokrajina (agrarna). Še druga njegova varianta vsebine regije: "Regija je večja ali manjša pokrajina, ki izkazuje določeno svojskost glede na prevladujoče naravne ali družbene pojave oz. je odraz njihovega medsebojnega prepletanja in se s tem razlikuje od sosednjih ozemelj." (Vrišer, 1997, str. 6) Tretja Vrišerjeva opredelitev regije se nanaša na ekonomske (gospodarske) regije. Cilj ekonomskogeografske regionalizacije naj bi namreč bil ugotoviti in razložiti, kako se v pokrajini oblikujejo pod vplivom gospodarskih dejavnikov, to je proizvodnje, potrošnje in menjave, ter nekaterih družbenih razmer ozemeljske enote, ki jih družijo skupne gospodarske in družbene značilnosti. Le-te dajejo ozemlju določeno svojskost in celovitost (Vrišer, 1990, str. 6). Za razumevanje omenjenih definicij regije je potrebno opozoriti, da se Vrišer naslanja na staro literaturo. 
V slovenski geografiji se je poleg Ilešiča z opredelitvami pokrajinskih enot še največ ukvarjal Gams. Poskušal je potegniti ločnico med številnimi pojmi: prostor, predel, svet, cona, pas, področje/območje, provinca, rajon, pokrajina, regija (1984). Zavzema se za poenotenje geografske terminologije oziroma za odpoved preohlapnim oznakam v prid nekaterih terminov v smislu ene besede za en pojem. Za regijo predlaga, da bi jo uporabljali za družbenogeografski kompleks $v$ nasprotju s pokrajino, ki naj predstavlja naravnogeografski kompleks. Svoje predloge je oblikoval, ob uporabi nekaterih tujih leksikonov, le s pomočjo domače geografske literature v okviru triumvirata: Gams, Ilešič, Vrišer! Po mnenju Gamsa regija v geografiji ni oznaka razprostranjenosti enega pojava (rajon), temveč sinonim za pokrajino, ki pomeni specifično povezovanje naravnih in družbenih pokrajinotvornih elementov (Gams, 1977, str. 42). Avtor na isti strani piše, da posebnost geografije ni v tem, da povezuje naravne in družbene pojave $\mathrm{v}$ geografski kompleks, temveč $\mathrm{v}$ tem, da sta obe komponenti enakomerno ali vsaj enakopravno zastopani. Izjava, ki govori o odmiku od realnosti (in znanosti). Desetletje kasneje je Gams prepričan, da obstajajo regionalne strukture kot kompleks medsebojnega vplivanja (naravnih in družbenih dejavnikov), vendar je to raziskovalno prezahteven problem. Zato se odločamo za lažje probleme, to je specialne študije (Gams, 1987, str. 3). Gams osebno gleda na regijo očitno kot na homogena območja. Tako zagovarja panožne regionalizacije (geološka, temelječa na reliefu, podnebju, prebivalstvu itn.), ker imajo svoja območja večje ali manjše homogenosti. To spoznanje skuša prenesti v pouk; naloga regionalizacije Slovenije naj bi bila namreč v tem, da z najmanjšim številom bolj ali manj homogenih območij predstavimo osnovne pokrajinske razlike, ki se javljajo $\mathrm{v}$ naši državi (Gams, 2001, str. 10). Vse Gamsove obravnave in razumevanje regije pa moramo razumeti skozi njegov pogled, da regije niso objektiven, v naravi trdno omejen pojav, pač pa le z opredeljenimi (izbranimi) kriteriji zasnovana miselna shema, ki omogoča pokrajinske razlike poenostaviti v še obvladljivo podobo (Gams, 2000, str. 58).

S temeljnimi geografskimi pojmi se je ukvarjal tudi Radinja (1989), a predvsem z okoljskega vidika, kjer pa ni našel mesta za regijo. Pomembno je njegovo spoznanje, da je geografska terminologija $\mathrm{v}$ marsičem odprta, kar je posledica premalo kritične geografske misli, pa tudi širjenja in drobljenja geografske znanosti.

K. Natek se v kritiki "nove" regionalizacije (1998) dotika tudi vsebine regije. Njene značilnosti žal povzema le po leksikonih in enciklopedijah, ki zaradi (prevelikega) posploševanja ne ponujajo strokovno dovolj poglobljenih definicij. To je vidno iz vrtenja v začaranem krogu, ko se neprestano pojavljajo trditve, da regijo opredeljujejo "tiste značilnosti, po katerih se enota razlikuje od sosednjih" (str. 141).

Najnovejša opredelitev regije, namenjena pouku geografije Slovenije v srednjih šolah, je, glede na namen uporabe, do največje mere poenostavljena. Šlo naj bi za pokrajinskofunkcijsko zaokroženo enoto, ki se kaže v občutku pripadnosti prebivalcev tej enoti. Regija je opredeljena kot pokrajinska enota, ki je organizirana v zaključeno celoto (Klemenčič M. M., Lipovšek, 2002, str. 91).

Regija je območje, kjer se v socialnem prostoru materializirajo (so uprostorjeni) socialni odnosi med ljudmi (Drozg, 2004, str. 19). Regije so po mnenju Drozga metodološki konstrukti, umetne tvorbe, ki dajejo generalizirano in zelo posplošeno predstavo o pokraji- 
ni. Regijo naj bi določal eden ali več izbranih elementov. Takšno mnenje večine slovenskih geografov postavlja slovensko geografijo izven znanosti.

Pokrajina ali regija je sestavljena iz pokrajinskih sestavin, te pa iz cele vrste pojavov in procesov: pri površju so pomembni na primer naklon, ekspozicija, nadmorska višina, erozija, tektonika in podobno, pri prebivalstvu pa gostota, starostna sestava, naravni prirastek in podobno (Perko, 1998, str. 14). Kot bi bila regija suho drevo, kjer štejejo le veje, življenjski sokovi so pa očitno brezpredmetni. Da gre za povsem formalistično gledanje na regijo (pokrajino!?), kaže tudi Perkova izjava, da regionalnogeografske raziskave približno enakovredno upoštevajo naravne in družbene sestavine pokrajine (1992, str. 187).

Nenavadno gledanje na pokrajinske enote, ki jih običajno označujemo z regijami, ima Černe (1999). Govori namreč o geografskih območjih, ki pa so razumljena na več načinov. Prva opredelitev bi se pokrivala z življenjskim prostorom posameznika: "Vsak izmed nas pripada posameznim "geografskim območjem”, ki so opredeljena v večji meri s krajem, v katerem živimo, krajem, kjer delamo, in ljudmi, s katerimi delimo naše življenje.” (Černe, 1999, str. 298). Malo naprej avtor vsebino "geografskega območja" razširi s posameznika na skupnost in ji poleg materialne priključi še reprezentativno in simbolno vsebino. Zadrega glede poimenovanja geografsko območje je vidna s tem, da je pojem postavljen med navednice. Da je pojmovna nejasnost še večja, uporabi izraz "regionalen" za opredelitev prostorskega obsega (regionalna raven) in celo za skovanko "regionalna pokrajina". V prispevku so nekritično nanizana avtorjeva osebna gledanja in (necitirana) gledanja treh tujih avtorjev na tematiko "geografskih območij", ki bi lahko služili kot zanimiva iztočnica za resno strokovno obravnavo vsebine temeljnih geografskih pojmov, med njimi tudi regije.

Pri regionalizacije Slovenije bi pričakovali kot nekaj samoumevnega, da avtor opredeli osnovni pojem, na katerem temelji regionalizacija, to je regijo. Podobno kot Ilešič tega ni storil Plut (1999), čeprav je navedel definicije in poglede slovenskih geografov na regijo. Žal iz tega pregleda ne moremo izluščiti Plutovega pogleda na regijo. Lahko se naslonimo le na definicijo iz leta 1977, da gre pri regiji za med seboj različne pokrajinske enote, pri katerih naj bi poznali čim večje število elementov naravnega in antropogenega okolja (Plut, 1977).

Nedoslednost in nekritičnost opredelitve regije je vidna tudi iz Kladnikovega pregleda naravnogeografskih členitev Slovenije (1996). Kladnik povzema definicije za regijo avtorjev regionalizacij. Pričenja $\mathrm{z}$ ločevanjem med tipizacijo in regionalizacijo; za slednjo naj bi bilo značilno načelo individualnosti. Takoj se postavlja vprašanje vsebine individualnosti. Podobno je s pojmi enkratnost, edinstvenost regije in enotnost območja, pa tudi s "popolnim ujemanjem posameznih prvin" (Kladnik, 1996, str. 125). Razmerja med naravno pokrajino, kulturno pokrajino in regionalizacijo, ki v dobršni meri razrešujejo teoretične nedoslednosti pri "naravnogeografskih" regionalizacijah, je na primeru najmanj preoblikovane slovenske (alpske) pokrajine osvetlil Petek (2004). Ugotavlja, da so se v slovenskem alpskem svetu oblikovala območja s podobno rabo in spremembami rabe tal, vendar z različnimi družbenimi in/ali naravnimi razmerami (Petek, 2004, str. 311). To spoznanje odpira vrata k realnejšemu gledanju na pokrajinsko stvarnost in $\mathrm{k}$ iskanju pokrajinskih funkcijskih enot kot izhodišču za (pravo) regionalizacijo.

V zadnjem desetletju se v slovenski geografski literature mimo opredelitve regije, pogosto pojavlja obravnava regionalizma (na primer V. Klemenčič; Zupančič, 1992). Pojem 
je povezan nekako s tremi področji: usmerjanjem prostorskega (regionalnega) razvoja, politično-upravno delitvijo Slovenije in prostorsko (regionalno) identiteto. Podobno je s pojmoma regionalni razvoj (prim. Ravbar, 2004) in regionalne razlike (Černe, 1987), ki sta povezana z obravnavo kazalcev prostorskega (gospodarskega, socialnega) razvoja, ne da bi bila opredeljena vsebina in (s tem) obseg regije. Iz te zadrege se posamezni raziskovalci izvlečejo z uporabo funkcijskih ali homogenih "regij", ali pa uporabijo obseg statističnih in planskih regij ter upravnih enot.

Pomembno mesto v slovenski geografiji dobiva pojem problemska regija, prevzet iz političnih in planerskih krogov. Temeljita obdelava vsebine pojma $\mathrm{v}$ teoriji in praksi, ki jo je v magistrskem delu opravil Kušar (2003), je le potrdila neprijetno spoznanje, da slovenski geografi vse prevečkrat zapadamo pod strokovni vpliv sorodnih strok, pa tudi dnevne politike. Tako tudi "problemske regije" nismo znali izpeljati iz teoretsko jasno opredeljene (geografske) regije. Še več; zaradi vsebinske nedorečenosti pojma se kot zvončki spomladi pojavljajo vedno nove "regije", na primer zgostitvene (Kušar, Vintar Mally, 2004). Bolj kot kjerkoli drugje je pri regiji pomemben genetski (razvojni) vidik, torej njeno obravnavanje $\mathrm{v}$ prostorskem in časovnem okviru. Ker tega ni, tudi ni geografskega bistva regije, zato se pri "problemski regiji" nekritično prevzemajo predvsem ekonomski kazalci.

Strokovna nesuverenost (samovoljnost) in/ali prilikovanje sorodnim strokam in praksi se je lepo pokazala pri projektu v okviru Službe za lokalno samoupravo pri Vladi Republike Slovenije, kjer so pri pripravi strokovnih stališč do oblikovanja pokrajin sodelovali predvsem geografi (Pokrajine v Sloveniji, 1999).

Zanimivo je, da Ilešič ni opredelil regije (pogosto uporablja sopomenko rajon), temveč na široko razpravlja o primernosti opredelitev tujih avtorjev. Tudi Malovrh (1958) v zgodnjem obdobju uporablja pojem rajon za oznako gospodarsko-geografskih enot, ki naj bi bile homogene. Za takratni čas je izredno zanimivo njegovo gledanje na organizacijo geografskega prostora: "Prostor, kjer žive in gospodarijo ljudje, je dejansko že razdeljen oziroma se postopoma razdeljuje $\mathrm{v}$ manjše enote, katerih ustroj pa seveda ni očitno zaznaven in jih zategadelj lahko spoznamo šele z raziskovanjem.” (Malovrh, 1958, str. 81). Nič manj zanimiv in za sodobnike poučen je Malovrhov pristop k rajoniranju, ki ne sme biti izčrpano s statistično obdelavo ter kartografsko zabeležbo količinskih in kakovostnih podatkov o ustreznih činiteljih, ker ne privedejo do spoznanja strukturnega bistva rajonov. Ti so namreč individualizirane enote gospodarskega prostora. Ko Malovrh govori o načelu homogenosti in gospodarske gravitacije središča, ju ne postavlja kot poljubni izbiri (kar se dogaja sodobnim geografom). Malovrh je uporabil načelo homogenosti pri rajoniranju jugoslovanskega gospodarskega prostora kmalu po vojni, ko je bila gospodarska struktura verna odslikava naravnih razmer. Gospodarsko-gravitacijska središča pa naj bi po mnenju Malovrha postala pomembni oblikovalci rajonov šele na višji stopnji gospodarskega razvoja. "Med obema meriloma (gospodarske homogenosti in gospodarske gravitacije) ni moči izbirati po volji." (Malovrh, 1958, str. 83).

Tudi nekateri drugi avtorji razglabljajo o načelih, pristopih in metodah regionaliziranja, ne da bi najprej pojasnili vsebino izhodiščnega pojma. Iz omenjenih razprav bi bilo možno izluščiti številne osebne poglede raziskovalcev na regijo, vendar bi podrobnejša obravnava regionalizacijskih pristopov presegla začrtani okvir razprave, pa tudi po obsegu 
zahteva samostojno obravnavo. Velik del pogledov ima isto izhodišče: formalistično/tradicionalistično gledanje na regijo. Problem postane še hujši, naravnost kaotičen, ob enačenju vsebine pojmov pokrajina in regija. V tej zmešnjavi potem ni nič čudnega, če beremo o "regionalnogeografskih regijah" (Gams, 1994, str. 128).

\section{REGIONALNA IDENTITETA V SLOVENSKI GEOGRAFSKI LITERATURI}

S sodobnim pojmovanjem regije je povezan pojem regionalne identitete. S preučevanjem tega pojava se je slovenska geografija primaknila k sodobnim temam, ki jih tuja literatura obravnava v okviru pojma regija.

Černe (1999, str. 299) izpostavlja gospodarski, tržni vidik identitete, ko investicije v potrošnjo, prodajanje "imagea” kraja, tekmovanje pri opredeljevanju kulturnega in simbolnega kapitala, oživljanje krajevnih tradicij ter različne privlačnosti za potrošnika postajajo del vsakodnevne konkurence med različnimi območji. To trditev pa takoj naprej na določen način zanika, ko trdi, da modernizacija vpliva več ali manj negativno na prostorsko in regionalno identiteto. Prebivalci na določenem območju skušajo varovati, ščititi prostor, na katerem živijo, saj izraža najbolj intimno povezavo s človekovim življenjem. Bivanje naj bi namreč pomenilo v prvi vrsti “identifikacijo z okoljem”, zato je izrednega pomena odkrivanje, spoznavanje in razumevanje različnih pomenov, ki so potencialno prisotni v različnih geografskih območjih. Na tem mestu pa ostaja odprto vprašanje o načinu razmišljanja/pristopa o geografskih območjih; Černe zagovarja gledanje na geografska območja kot na proces, ne pa kot na stvari oziroma predmete. Takšen pristop izhaja iz sodobnih (geografsko enostranskih) pogledov na razvoj pokrajine pod vplivom globalizacije. Če pa vemo, da sta pokrajinska in regionalna struktura ter še posebno identiteta odsev naravnih in družbenih struktur ter procesov, bi bili le-ti vredni geografske obravnave. Ali drugače: socialnega prostora (najbrž) ne moremo obravnavati brez fizičnega prostora.

Zupančič (2003, str. 46) se temeljito ukvarja z identiteto, predvsem narodno, ki jo opredeljuje $\mathrm{z}$ naslednjimi sestavinami:

- kulturno-jezikovno,

- zgodovinsko ali časovno,

- prostorsko,

- gospodarsko-socialno,

- politično.

Narodna identiteta je notranje dokaj raznolika tudi zaradi razlik v regionalni strukturi in regionalni identiteti. Na nižji ravni naj bi bile hierarhično razporejene deželne, regionalne, območne in krajevne (lokalne) identitete. Regionalne identitete naj bi bile vezane na določeno homogenost, na primer naravne značilnosti, kulturne in zgodovinske tradicije (Kras, Pivka, Bela krajina, Prlekija).

Raziskava na Gorenjskem (Klemenčič, M. M., 1995; 1997) je pokazala, da je lokalna identiteta odličen kazalec (ne)stabilnosti družbenogeografskih razmer oziroma stopnje (ne)uravno- 
teženosti med lokalno družbo in njenim naravnim okoljem. Z (lokalno) identiteto se tako neposredno spuščamo $\mathrm{v}$ jedro vsebine regije.

Bufon (1999) identiteto navezuje na teritorialnost; "anonimnemu” območju elementi in vidiki dajejo poseben značaj, opredeljujejo teritorialno enoto, kateri v njej delujoče dominantne družbene skupine določijo ime, obseg in meje. Identiteta in teritorialnost naj bi imeli različne in mnogokrat sočasne dimenzije.

\section{REGIJE V GEOGRAFSKIH IN DRUŽBENOGEOGRAFSKIH REGIONALIZACIJAH SLOVENIJE}

Dobršen del razprav o naravi regije se razjasni ob pogledu na posamezne regionalizacije. V pretres smo vzeli štiri najbolj izpostavljene: dve ekonomsko-geografski (Ilešič, 1958; Vrišer, 1990) geografsko (Ilešič, 1972) in sonaravno (Plut, 1999). Pri omenjenih regionalizacijah nas je zanimalo dvoje: meje med največjimi regijami (makroregijami) in število le-teh. Obe sestavini regionalizacij naj bi pokazali notranjo organizacijo slovenskega prostora in stopnjo stabilnosti regionalnih enot.

Čeprav se omenjene regionalizacije razlikujejo med seboj glede izhodišč (kriterijev), pa so si v izrisu regij zelo podobne. Iz tega lahko potegnemo (pred)sklep, da se družbenogeografske regionalizacije močno približujejo celovitim, geografskim regionalizacijam, saj družbenogeografske regije nastajajo $\mathrm{v}$ naravnem okolju, ki jih $\mathrm{v}$ dobršni meri določujejo. Oglejmo si najpomembnejša izhodišča posameznih regionalizacij.

Ilešičeva ekonomsko-geografska regionalizacija (1958) upošteva funkcijski kriterij. Posebno pri večjih enotah je izpostavljen gravitacijski vidik, medtem ko za submezoregije ugotavlja, da so gospodarsko še vedno močno individualizirana območja s slabo razvitimi centralnimi kraji. Ljubljana, Maribor in Celje z močnimi gravitacijskimi vplivi so opredeljeni kot makroregionalna središča. Vzhodnodolenjsko-spodnjeposavska in Primorska makroregija nimata makroregionalnih središč, ampak ju sestavljajo štiri oz. dve mezoregiji. Pri obeh izpostavlja gravitacijski vpliv dveh makroregionalnih središč izven Slovenije: Zagre-ba in Trsta.

Vrišer (1990) pri ekonomskogeografski regionalizaciji Slovenije povezuje ekonomskofunkcijsko in ekonomsko-homogeno načelo. Homogenost izhaja iz gospodarske usmerjenosti posameznih območij v okviru primarnih, sekundarnih in terciarnih dejavnosti. Čeprav je homogeno načelo vzeto kot dopolnilni kriterij ob nosilnem, to je funkcijskem, pa se nam za slovenske razmere ne zdi ustrezen. Slovenska gospodarska struktura je tudi v prostorskem pogledu zaradi relativne razvitosti tako pestra, da ni pravih homogenih območij, razen na zelo ozki lokalni ravni. Temeljni kriterij Vrišerjeve regionalizacije pa izhaja iz funkcijske (gravitacijske) vloge centralnih krajev različne stopnje. Slovenija je razdeljena na 12 regij.

Geografske regije Slovenije (Ilešič, 1972) naj bi bile, vsaj zaradi poimenovanja, vrh regionalizacij Slovenije. Splošno uporabna regionalizacijska shema Slovenije naj bi po Ilešičevem mnenju morala upoštevati poleg naravnih enot še zgodovinsko in sodobno policentričnost Slovenije. Po tej shemi je Slovenijo razdelil na pet glavnih regionalnih enot; dve 
imata značaj makroregij, ostale pa so sestavljene iz mezoregij. Regionalizacija je nastala $\mathrm{v}$ času izrazite prevlade dveh središč: Ljubljane in Maribora in šibke moči regionalnih središč (razen Celja in Kranja).

Zadnja regionalizacija (Plut, 1999) ima zelo obetaven naslov; izdelana naj bi bila po sonaravnih kriterijih. Plut izhaja iz pokrajinskih/naravnogeografskih/ekoloških regionalizacij na eni strani ter ekonomskogeografskih na drugi strani. Njegove ambicije gredo naprej $\mathrm{v}$ smeri regionalnogeografske členitve, kjer bi "stabilnejši pokrajinskoekološki in naravnogeografski vidiki postali enakovredni dinamičnejšim ekonomskim in upravnopolitičnim vidikom ter občutku regionalne pripadnosti prebivalcev." (Plut, 1999, str. 14). Za razliko od prejšnjih regionalizacij avtor prvič izpostavlja identitetni vidik, kar je vsekakor zanimiv element. Nekoliko vprašljivo pa se zdi mnenje o nujnosti enakovrednega upoštevanja naravnega in družbenega kompleksa, saj diši po uravnilovki (na primer kot križišče dveh enakovrednih cest - SSKJ, str. 200).

Izpostavljen je pomen porečij kot nosilcev sonaravnega gospodarskega razvoja. Posebno pozornost pa vzbuja uporaba in razumevanje pojma sonaravnost. Kot je vsebina pojma sonaravnost zelo meglena celo v strokovni literaturi, tako je tudi z njeno uporabo pri obravnavani regionalizaciji. Še več, nedorečenost pojma pripomore k pavšalnim ugotovitvam in med seboj nasprotujočim se pogledom. Tako je s trditvijo, da ekonomskogeografski kriteriji sonaravne členitve oziroma sonaravno zasnovane členitve mezoregionalnega nivoja poudarjajo pomen čim večje geografske homogenosti območij, gospodarne rabe regionalnih virov in dostopnosti delovnega mesta in storitev. V nasprotju s to trditvijo Plut stalno izpostavlja pomen pokrajinske pestrosti (na primer pri porečjih); še več, s tega vidika (geografske homogenosti !?) izbere Vrišerjevo pretežno ekonomsko-funkcijsko opredelitev mikroregij. Ob tem je odveč pripomniti, da so Plutove mezoregije pokrajinsko in gospodarsko izrazito heterogene. Tudi število regij na različnih ravneh avtor opredeljuje subjektivno, brez kakršnekoli objektivne analize. Tako je med drugim arbitrarno določil 25.000 prebivalcev kot spodnji prag za pokrajino. Plut je Slovenijo razdelil na osem makroregij. Čeprav Plutovo regionalizacijo lahko primerjamo s predhodnimi, saj izhaja iz njih, pa ima nekoliko drugačna teoretska izhodišča. Ne gre le za regionalizacijo Slovenije per se, ampak se jo uporablja kot instrument za razvojne namene; to je v skladu s sodobnimi, socialno, plansko in okoljevarstveno usmerjenimi pristopi do regije in pomeni družbeno angažiranost, hkrati pa nevarnost, da na račun izpostavljanja razvojnih pogledov zanemarimo znanstveno/strokovno neoporečen pristop. Plutova želja po usmerjanju (sonaravnega) razvoja Slovenije prek njene regionalizacije je razvidna iz naslova regionalizacije, čeprav mu še ni uspelo dovolj jasno konkretizirati "sonaravnostnih" kriterijev in končnih ciljev.

\section{Meje regij}

Skladnost (prekrivanje) meja regij med obravnavanimi regionalizacijami je sorazmerno velika. Razen v primeru občine Slovenske Konjice, ki jo le Vrišer vključuje v celjsko območje, je edinapomembnejša izjema zahodni del Slovenije. Precej zadrege je namreč z idrijskim območjem, ki ga le Ilešičeva ekonomskogeografska regionalizacija prisoja osrednjeslovenski (ljubljanski) makroregiji, čeprav je tudi pri ostalih avtorjih čutiti zadrego 
Graf 5: Prekrivanje meja štirih regionalizacij Slovenije.

Figure 5: The accordance of the boundaries of four regionalizations of Slovenia.

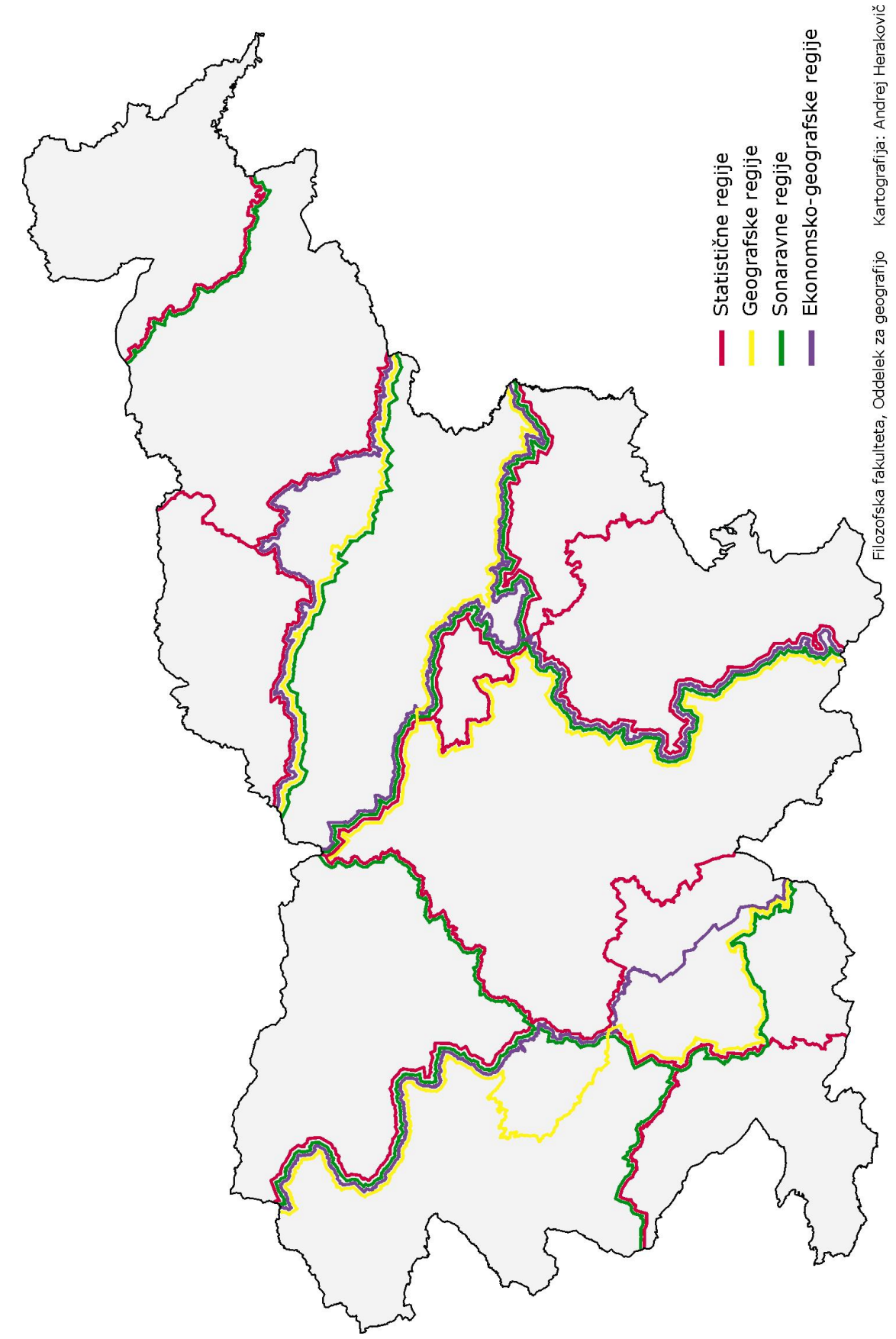

Vir/Source: Ilešič, S., 1958; 1972; Vrišer, I., 1990; Plut, D., 1999. 
pri vključevanju idrijske občine na primorsko stran. Pogledi na potek meja med regijami so še bolj različni na Notranjskem, kjer sta očitno v ospredju dve dilemi: pripadnost postojnske občine osrednjeslovenski ali primorski regiji na eni ter (ne)obstoj Notranjske kot regije na drugi strani.

Potek meja največjih, (makro)regionalnih enot kaže na njihov trojni značaj; naslonile so se na geografske meje (gorska/hribovska slemena oz. razvodnice), na zgodovinske upravne meje in na meje med gravitacijskimi območji. Slednji razlog se zdi najmočnejši.

Očitna je prevlada poteka meja v dinarski smeri. Gre za meje po gorskih slemenih oz. razvodnicah, na katere so se oprle srednjeveške upravne (deželne) in novejše občinske meje.

Najzahodnejša meja med Kaninom in Snežnikom je najlepši primer omenjenih dejstev. Razvodnica med jadranskim in črnomorskim povodjem, dinarska smer, v zgornjem delu ponovitev meje med nekdanjo Goriško grofijo in deželo Kranjsko, v spodnjem pa preplet omenjenih potez z dopolnilnim opiranjem na občinske (komunalne) meje.

Meja med Kranjsko in Štajersko bi se zelo približala idealni meji, potekajoči po gorskih slemenih in Savi, povrhu še v dinarski smeri, če je ne bi v spodnji polovici "zmotil" novejši družbenogospodarski razvoj. Na deželni meji je nastalo rudarsko-industrijsko območje, ki je razvilo lokalno/regionalno identiteto, izraženo celo s poimenovanjem (Zasavje). Od tu naprej se je nekdanja deželna meja razklala: severni del se je povzpel na priostrene vrhove Bohorja in sosednjih vrhov, južni krak pa je med Kumom in Rogom poiskal mejo med novomeškim in ljubljanskim gravitacijskim območjem. Meja po Savi je ostala upravna meja do srede 20. stoletja. S komunalnim sistemom se je začelo gospodarsko in oskrbno povezovanje obeh bregov Save in pripeljalo do oblikovanja nove, družbenogospodarske identitete Spodnjega Posavja, v zavesti ljudi pa še vedno ostaja trdno zasidrana stara deželna meja na Savi med "Kranjci" in "Štajerci". Z razvojem Novega mesta se je območje odlepilo od preveč oddaljenega Celja in bližnjega Zagreba in se (ne preveč dejavno) vključilo $\mathrm{v}$ dolenjsko regijo.

Tretja ločnica med mariborsko in celjsko (makro)regijo je izrazito orografska, potekajoča po slemenih hribov, ki so podaljšek Karavank. V severozahodnem delu je bila to hkrati deželna meja med Koroško in Štajersko, potekajoča v alpski smeri, od Uršlje gore dalje pa $\mathrm{v}$ omiljeni dinarski smeri.

Najnovejša medregionalna ločnica razmejuje mariborsko od murskosoboške (pomurske) regije. Položaj je zelo podoben tistemu v Spodnjem Posavju. Z dvigom pomena Murske Sobote se je s Prekmurjem predvsem oskrbno in infrastrukturno povezala nekdaj štajerska Prlekija. Tako je bila presežena dolga stoletja trajajoča meja na Muri, ki pa v zavesti ljudi še vedno ostaja trdno zasidrana.

\section{Obseg regij}

Obravnavane referenčne regionalizacije imajo različno število temeljnih (makro)regij: Ilešičeva 5, Vrišerjeva 12 in Plutova 8. Njihovo število odraža na eni strani objektivno stanje, na drugi pa poglede tistega, ki regionalizira. Prekrivanje meja osnovnih regij nas navaja na misel, da je najprimernejša delitev Slovenije na pet regij. Sklep dobi formalističen značaj 
ob dejstvu, da sta Ilešičevi regionalizaciji nastali v precej drugačnih družbenogospodarskih razmerah kot ostali dve. Ilešič se je naslonil na urbani sistem, ki je bil v 60. in 70. letih 20. stoletja slabo razvit, posebno na ravni regionalnih središč. Njihova okrepitev je postavila drugačna prostorska razmerja, ki jih novejši dve regionalizaciji upoštevata. Ob tem se postavlja vprašanje hierarhične razčlenjenosti slovenskih regij. Je možna še drugačna temeljna členitev slovenskega ozemlja? Zgodovinski razvoj, upravne razdelitve od srednjega veka dalje, gospodarska struktura, kulturni vidiki, občutek pripadnosti nas usmerjajo na razmejitev Slovenije na tri enote: Vzhodno Slovenijo, Osrednjo Slovenijo in Zahodno Slovenijo; v ljudskem jeziku bi bile to Štajerska (z vključenima Koroško in Prekmurjem). Kranjska (brez dela Notranjske) in Primorska. Trojane in Postojnska vrata ostajata simbolni ločnici med navedenimi tremi deli Slovenije. Vse tri enote enote imajo vsaj poltisočletni razvoj (deželne) identitete, ki ima podkrepitev v naravnogeografskih mejah, gospodarskem razvoju in središčih; v tem pogledu je izjema le Primorska, ki bi ji kot središče organsko pripadal Trst.

Najnovejši razvoj prometne infrastrukture in krepitev regionalnih središč (nastajanje novih univerz in visokošolskih središč) nakazuje nov premik v krepitvi družbenogospodarske moči in s tem identitete na regionalni ravni. Glede tega se zdi, da je dejanskemu stanju primernejša delitev Slovenije na več (osem, dvanajst) regij. K temu nas navajajo tudi težnje v slovenski Cerkvi, ki razmišlja o oblikovanju po obsegu manjših škofij namesto sedanjih treh velikih. Takšni trendi nas ne smejo zavesti, da bi izgubili izpred oči celotnega obzorja in bi bili, kot s plašnicami opremljeni konj, zazrti le $\mathrm{v}$ en sam regionalni nivo.

Avtocestni križ lahko primerjamo z učinkom globalizacije, razvoj visokošolskih središč pa (lokalni) odgovor nanjo. Kot pri vsaki stvari na Zemlji in v vesolju je na eni strani vedno prisotna težnja po spremembah, na drugi strani pa po vzpostavljanju ravnotežja. Zato mora biti stroka posebno pazljiva pri razpoznavanju (diagnosticiranju) novih razvojnih silnic, hkrati pa ugotavljati stopnjo ravnotežja v prostorskem razvoju.

Slovenija - svet v malem. Naravnogeografske razmere, zgodovinski razvoj, kulturnonarodnostno pestro sosedstvo in gospodarsko-politični razvoj ne dovoljujejo, da bi regionalno razčlenjenost Slovenije primerjali s tistimi v drugih državah in se jim skušali približati. Ločevati je treba med strokovnim in aplikativnim načinom gledanja na regije. Slovenija je tudi v pogledu strukture regionalne identitete posebnost med evropskimi državami. Ob tem se seveda vedno znova postavlja praktično vprašanje: katero raven hierarhije regij oz. kakšno hierarhijo regij sploh uporabiti kot osnovo za učinkovit družbenogospodarski in prostorski razvoj Slovenije. Vsakršna učinkovitost razvoja izhaja iz stopnje aktiviranja lokalnih virov, ki ji daje pravi zagon lokalna/regionalna identiteta. Lokalna/regionalna samouprava je edino zagotovilo za to, da se bo Slovenija razvijala učinkovito. Za to pa ni potrebno razvijati vseh dejavnosti na vseh stopnjah (mnogostopenjske) hierarhije regij. Gospodarska struktura naj bo prilagojena tehnološkim in splošno gospodarskim zahtevam primerno na ustrezni prostorski ravni. Kulturne in deloma izobraževalne ustanove naj se bolj neposredno približajo lokalnim/regionalnim posebnostim itn. Prostorska identiteta kot nosilni razvojni dejavnik je spremenljiva kategorija, tako po obsegu območja kot po vsebini identitete. Pomembno je, da ji stroka sledi, državna uprava pa omogoči polni razvoj. 


\section{NASTAVKI ZA GEOGRAFSKE REGIJE V SLOVENIJI}

Naravno okolje v Sloveniji je človek toliko preobrazil, da moramo slovensko pokrajino brez vsakega zadržka obravnavati kot kulturno pokrajino. Njeno podobo, zgradbo in razvoj določuje razmerje med naravnim okoljem in družbo. Pri tem odnosu družba vodi "igro". Za razlago dogajanja v pokrajini je potrebno izhajati iz splošnih razvojnih (civilizacijskih) stopenj družbe (Klemenčič M. M., 2003), ki nam nakazujejo problemske poudarke prostorskega razvoja. Z razvojem družbe se razširja krog razvojnih dejavnikov in s tem posledično zmanjšuje zaprtost (samozadostnost) tudi zelo majhnih območij.

Graf 6: Sestavine kulturne pokrajine.

Figure 6: The components of the landscape.

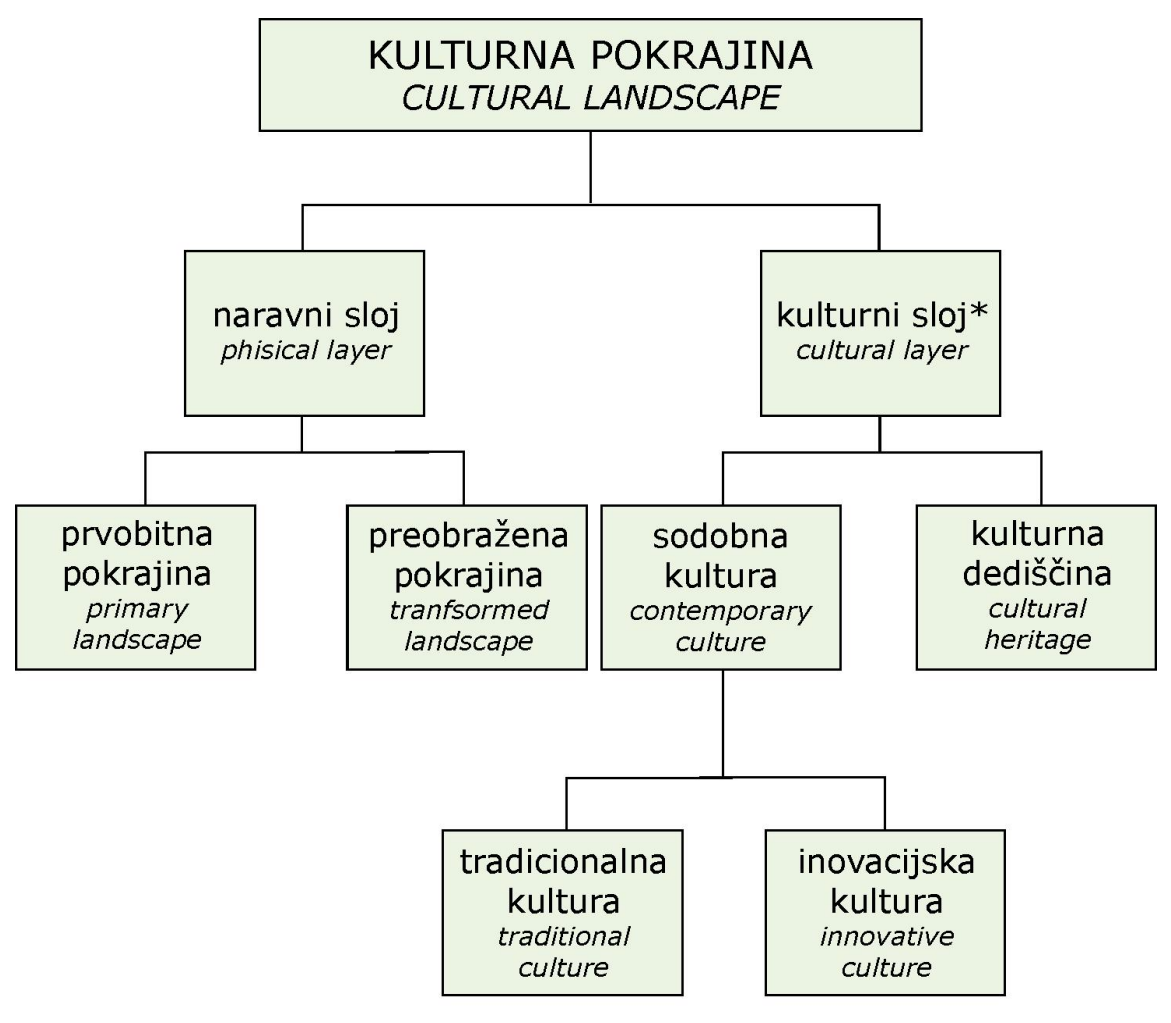

* materialna in duhovna kultura material and spiritual culture

Oblikovanje: Andrej Herakovič

Vir/Source: Vedenin, Ju. A., 1990.

Pri razumevanju dogajanja v pokrajini in njenem vrednotenju so nam lahko v veliko pomoč različni načini gledanja na strukturo pokrajine, kakršen je na primer Vedeninov (1990). Njegova shema izhaja iz enotnosti pokrajine, ki je edino kulturna pokrajina. Znotraj nje razpoz- 
nava dve temeljni sestavini: naravo in kulturo. Kulturo razumeva $v$ najširšem smislu, torej materialno in duhovno. Na ta način je $\mathrm{v}$ enotnosti zajel sodobno stanje, preteklost, ki je vplivala na sedanjost, $\mathrm{v}$ določeni meri pa tudi na prihodnost, ko $\mathrm{v}$ pokrajini razpoznava inovacijsko kulturo. Tako je dosegel večplastno integriranost geografskega pristopa; "povezal" je fizičnogeografsko in družbenogeografsko sfero, materialno in duhovno sfero (identiteta) ter časovno in prostorsko sfero.

Če ostajamo na trdnih (geografskih) tleh in dogajanj v pokrajini ne zožimo le na (socialno-ekonomske) odnose (ne sublimiramo pokrajine), nam Vedeninova shema nudi primerno orodje za razpoznavanje bistva in smeri razvoja pokrajine. Iz sheme je tudi razvidno preseganje umetno (ideološko) ustvarjenih nasprotij med naravnim okoljem in družbo. Pokrajina ni dvojna, sestavljena iz naravnega okolja in družbe, temveč je enovita. Če geografa zanima preobrazba pokrajine (stanja v praktičnem smislu ni, vsaj v času ne!), potem išče zakonitosti (pravilnosti, splošnosti) njenega razvoja.

Ko iščemo vzorce organiziranosti in razvoja pokrajine v luči regije, je naša pot usmerjena v pretres nosilnih razvojnih dejavnikov. Izločiti moramo kratkotrajne in epizodne razvojne dejavnike, da se nam razkrijejo trajnejši (tehtnejši).

\section{Vpliv družbenogospodarskih razmer na značaj regije}

Širše družbenogospodarske razmere določujejo značaj regij: njihovo velikost, zgradbo, način in stopnjo povezanosti s sosednjimi regijami itn. Če poenostavimo in posplošimo razmere v zadnjem stoletju, potem lahko razlikujemo tri vrste (stopnje) družbenogospodarskih razmer, ki so oblikovale organizacijo prostora in s tem tudi regij: agrarno, industrijsko in informacijsko (globalizirano).

Agrarna doba izkazije tesno povezanost naravnih razmer in načina gospodarske rabe. Pokrajinski tipi so v veliki meri določali gospodarsko usmeritev največjega dela prebivalcev. Izoblikovala so se gospodarsko (kmetijsko) homogena območja, ki so se pokrivala s pokrajinskimi tipi (Brkini, Kras, Goriška Brda, Bloke, Suha krajina, Haloze, Dravsko polje, Bohinj, Trenta, itn.). Na tej osnovi se je izoblikoval ustrezen način življenja in občutenja domače pokrajine. Na višji ravni se je predvsem v okviru dežel prek upravnih funkcij oblikovala deželna (regionalna) identiteta (kranjska, štajerska, koroška, goriška), kasneje pa še identiteta na nižji ravni (gorenjska, dolenjska, notranjska). Identitetna območja so bila jasno razmejena z naravnimi in upravnimi mejami.

Industrijska doba je $\mathrm{z}$ gravitacijskim načelom organiziranja gospodarstva $\mathrm{v}$ izhodišču zavrgla predhodni homogeni način organiziranja gospodarstva. Vsaj v Sloveniji so bila novo nastala gravitacijska območja gospodarsko in pokrajinsko heterogena. Najlepši primer takšnih enot, ki so dobile celo institucionalni okvir, so bile stare občine (komunalni sistem). Razbile so nekdanje pokrajinsko-gospodarsko homogene enote (na primer Brkine, Kras, Haloze), na drugi strani pa povezovale zelo različne pokrajinske enote (na primer občine $\mathrm{v}$ Spodnjem Posavju, ljubljanske, murskosoboška, tolminska, radovljiška občina). Pomembno mesto v oblikovanju prostorske organiziranosti so dobila centralna naselja pete stopnje po Vrišerju. Ne smemo pa zaobiti Zasavja kot tipičnega otroka industrijske dobe, ki ga po gospodarski usmerjenosti lahko štejemo za edino gospodarsko homogeno območje indus- 
trijske dobe. Ob tem pa ni zanemarljivo, da ravno ta industrijska "čistost" vriva območje v hierarhični sistem slovenskih pokrajin na dokaj neugoden način zaradi nesorazmerja med številom prebivalstva in zgoščenostjo gospodarstva na eni strani ter velikostjo ozemlja na drugi strani; podobno je s postojnskim "primerom", le v obratni smeri. Med dejavnike oblikovanja prostorskih enot lahko uvrščamo gospodarski, urbani, demografski razvoj in razvoj prometne infrastrukture. Kljub močni družbenogospodarski preobrazbi in prostorski reorganizaciji, ki ju je povzročila industrializacija, sta se v veliki meri ohranili lokalna in regionalna identiteta.

Informacijska doba (doba globalizacije) je močno zrahljala notranjo povezanost ožjih območij. Odprtost svetu prek številnih povezav slabi trdnost lokalne/regionalne identitete; slabi navezanost na domače okolje, hkrati pa postajajo meje med identitetnimi območji vse manj jasne. Slovenija je v globalizacijskih procesih postala lokalno območje. Na drugi strani se s politiko endogenega razvoja skuša utrjevati lokalno/regionalno identiteto, ki je nosilni dejavnik tovrstne politike. Dinamičnost in konkurenčni boj družbenogospodarskega razvoja vplivata na to, da se razmerja moči med pokrajinami hitro spreminjajo. Regionalni razvojni dejavniki (gospodarstveniki, politiki, združenja civilne družbe) zato krepijo zahteve po razvoju, na primer z ustanavljanjem visokošolskih središč in upravno formalizacijo (zahteva po ustanovitvi lastne upravne -pokrajinske- enote). Takšen razvoj je povsem v skladu s Paasijevo shemo idealnega razvoja regije. Na ta način se krepi srednja (regionalna) raven hierarhije regij; prvo stopnjo (lokalno) predstavljajo območja na občinski ravni. Omenjeno drugo stopnjo hierarhije območij predstavljajo pokrajine s historično razvito identiteto, na primer Prekmurje, Koroška, Savinjsko, Gorenjsko, Dolenjsko, Goriško, Slovenska Istra, Notranjsko, Bela krajina in območja z mlado (Zasavje) ali nastajajočo identiteto (Spodnje Posavje). Tretja (makroregionalna) raven se opira na historične dežele (Štajersko, Kranjsko) in v novejšem času (pre)oblikovano Primorsko. Ugovori, da teritorialno majhna Slovenija ne prenese trostopenjske hierarhije regij, so neumestni, če ostajamo na strokovnih (geografskih) tleh. Upoštevati moramo močno razvito identiteto, ki ima svojo utemeljitev tudi v naravnih razmerah (porečja oz. razvodnice). Kapitalski, blagovni, informacijski in osebni tokovi se po svojih (ekonomskih) kriterijih razlivajo po državi in stremijo po maksimalnih (gospodarskih) učinkih. Notranja lokalna/regionalna moč, ki jo v največji meri krepi samozavest (zaupanje v lastne sile) prek identitete prebivalcev, je zagotovilo za uravnotežen prostorski razvoj Slovenije.

\section{Pokrajinsko-funkcijske enote Slovenije}

Verjetno najbolj verodostojna členitev slovenskega ozemlja je tista, ki sloni na porečjih. Slovensko ozemlje obsega pet med seboj vzporedno in v dinarski smeri potekajočih porečij: soško-reškega, savskega, savinjskega, dravskega in murskega. Omenjeni bazeni so z ravninsko-dolinsko pokrajinsko strukturo omogočili razvoj lokalnega gospodarskega in urbanega sistema. Nosilci razvoja porečij so centralni kraji 5. stopnje po Vrišerju, razen v primeru Ljubljane in Maribora, ki sta povečala svoj pomen na račun velikosti gravitacijskega območja in posebnega (upravno-prometnega) položaja. Gravitacijski vidik je postal nosilec 
prostorskega razvoja pa tudi krepilec in oblikovalec lokalne/regionalne identitete. Na zgodovinskih deželah oblikovana zavest pripadnosti ljudi se nadaljuje v okviru gravitacijskih območij večjih oskrbnih središč. Še največ problemov z ohranjanjem regionalne idetitete ima Notranjska. Njena šibka populacijska in gospodarska moč se le stežka upira "agresiji" gravitacijskih vplivov Ljubljane, Kopra in Nove Gorice.

Naravne, predvsem reliefne razmere so po srednjeveški prostorski razbitosti gospodarskih in upravnih enot dobile vlogo nosilcev razmejevanja večjih prostorskih enot predvsem v upravnem pogledu (deželne meje), pa tudi v gospodarskem; Gorenjska, Dolenjska in Notranjska so v veliki meri imele značaj pokrajinske in gospodarske homogenosti. V sodobnosti so razvodnice celo bolj izrazite razmejevalke med pokrajinskimi enotami kot $\mathrm{v}$ preteklosti; to velja za Notranjsko, Spodnje Posavje in Pomurje. Tako lahko izpostavimo štiri pokrajinske ločnice, ki razmejujejo pokrajinsko-funkcijske enote Slovenije:

- savsko-soška razvodnica s podaljškom približno po rapalski meji,

- savsko-savinjska razvodnica,

- dravsko-savinjska razvodnica (podaljšek Karavank) in

- dravsko-murska razvodnica.

Sodoben razvoj, predvsem cestne infrastrukture, prispeva k prepustnosti meja. Po tej logiki naj bi se območja povezovala in oblikovala večje funkcijske enote. V slovenskem primeru lahko predvidevamo tripolno členitev z nosilci: Maribor (Štajerska s Prekmurjem in Koroško), Ljubljana (osrednjeslovensko območje, Kranjska), Koper-Nova Gorica (Primorska). Pri Primorski je potrebno upoštevati možnost krepitve obeh središč s prekomejnim sodelovanjem. Pri vsakem predvidevanju sprememb v organizaciji prostora je potrebno, poleg dinamičnosti in povezovanja, upoštevati tudi naslednji dve temeljni zakonitosti: inertnost (navezanost na domače okolje) in (ekonomski) prag, ki določuje (omejuje) razvoj oskrbnih dejavnosti višje stopnje, obseg dnevne migracije itn. Zaradi povečane mobilnosti in razvoja globalizacije lahko pričakujemo slabitev občutka pripadnosti ljudi domači regiji. Na drugi strani pa sodobni razvoj kaže, da različne skupine moči (odločanja) podpirajo razvoj lokalne/regionalne identitete $\mathrm{z}$ namenom, da uveljavijo svoje interese. Regionalna identiteta postaja pomemben razvojni (manipulativni) instrument ožjih ali širših območij.

\section{Občutek pripadnosti prebivalcev domači pokrajini}

Občutek pripadnosti prebivalcev domači pokrajini je posledica dolgotrajnejšega bivanja določene družbe $\mathrm{v}$ nekem okolju. Kolektivna zavest o pripadnosti domači pokrajini je dobrodošel znak za opredeljevanje geografsko zaokroženih območij. V okviru interdisciplinarne raziskave v letih 1998 - 2000 (Polič et al., 2002), kako si ljudje predstavljajo Slovenijo in njen razvoj, je bila pozornost namenjena tudi predstavam ljudi o obsegu potencialnih upravnih enot druge stopnje (pokrajin). Anketirani prebivalci so se opredeljevali do obsega pokrajine, ki jo obvladuje domače središče. Rezultati so zelo ilustrativni (M. M. Klemenčič, 2002) in praktično v vsem potrjujejo geografske predstave (spoznanja) o lokalni/regionalni identiteti. Iz kartografske predstavitve rezultatov je razvidno, da je v primeru posameznih 
središč velika večina odgovorov zelo jasno začrtala obseg domače pokrajine ("črni del tarče"). Zelo majhen del anketiranih je razširil obseg domače pokrajine celo na nerazumno veliko območje. To si razlagamo s tem, da je anketiranec doseljen in še ni vključen v "kolektivno zavest", da ima zelo ohlapen (neodgovoren) odnos do domače pokrajine, ali pa da želi pomagati svoji pokrajini k večjemu obsegu.

Nekaj ugotovitev:

- prebivalci imajo zelo jasno izoblikovan občutek pripadnosti domači pokrajini;

- čim manjše je območje, tem bolj jasna je omejitev domače pokrajine;

- stare upravne meje so še vedno zelo močno prisotne v zavesti ljudi.

Graf 7: Območja pokrajin v Sloveniji po predstavah ljudi.

Figure 7: The provinces in Slovenia according to the imagination of the citizens.

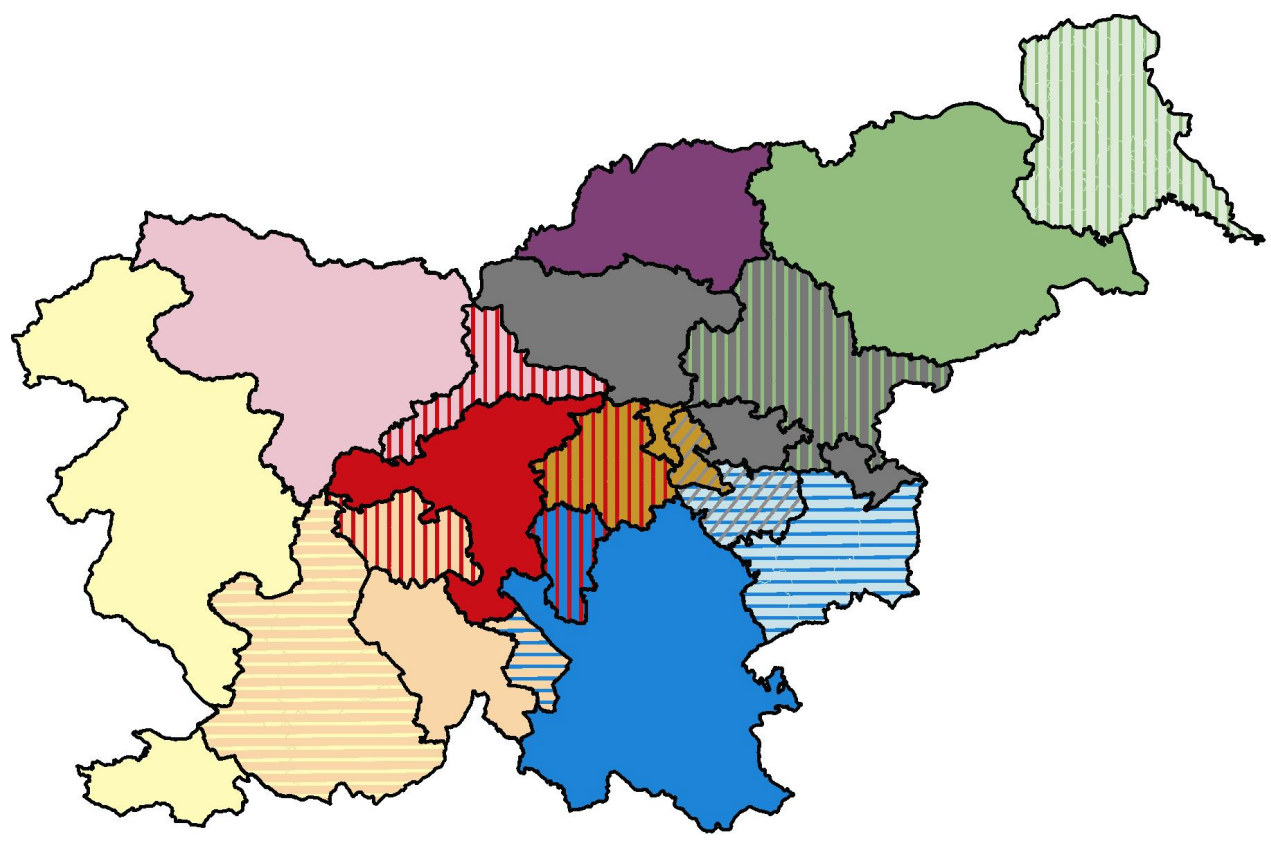

Mesto kot središče pokrajine/Town as a regional center

\begin{tabular}{|l|l}
$\square$ & Murska Sobota \\
$\square \square I I I$ & Maribor \\
$\square$ & Ravne \\
$\square$ & Celje \\
$\square$ & Trbovlje \\
$\square \quad$ Krško/Brežice
\end{tabular}

Novo mesto

Lubljana

Kranj

Postojna

Nova Gorica/Koper

Filozofska fakulteta,

Oddelek za geografijo

Avtor: Marijan M. Klemenčič,

Vir/Source: Klemenčič, M. M., 2002. 
Zgodovinska meja na Muri je presežena s prekmurske strani, ne pa tudi s prleške. Precej podobno je v Spodnjem Posavju. Prebivalci omejujejo domačo pokrajino na spodnjeposavske občine, ki imajo večino gospodarstva in prebivalstva na levem bregu Save, medtem ko precejšen del Novomeščanov prišteva v enaki meri Spodnje Posavje kot Belo krajino novomeški pokrajini. Koroška je v enakem obsegu pri Ravenčanih kot pri Slovenjgradčanih, čeprav so bili slednji več kot pol tisočletja pod Štajersko. Primorski del je le deloma jasno razmejen med Novo Gorico in Koprom.

Miselna slika pokrajin kaže dvojne temelje: na eni strani zgodovinsko zavest, na drugi pa sodobne družbenogospodarske in prostorske procese. Na srednji, regionalni ravni jasnost obeh izhodišč najbolj prihaja do izraza: Koroška, Prekmurje, Dolenjska, Gorenjska, Notranjska se očitno naslanjajo na zgodovinsko identitetno izročilo. Zasavje in Spodnje Posavje sta prej naštetim pokrajinam novodobni partnerici.

Še bolj zanimiva slika je na makroregionalni ravni. Možno je zaznati delitev Slovenije na tri velike (makro) enote s središči v Mariboru, Ljubljani in Kopru/Novi Gorici. V mariborskem primeru je pričakovan obseg predlagane pokrajine na skoraj celotno ozemlje nekdanje dežele (Spodnje Štajerske); je pa presenetljiv močan delež oseb, ki so k "mariborski pokrajini” dodali Prekmurje. S Trojanami, kjer se konča mariborska "vladavina”, se začenja ljubljanska "zgodba". Iz pokritja območja, ki naj bi pripadalo ljubljanski pokrajini", bi težko razpoznali nekdanjo Kranjsko; očitnejši je znak, da gre predvsem za gravitacijski vidik. Odgovori o obsegu koprske in novogoriške "pokrajine" vzbujajo podobno presenečenje kot v primeru mariborskega območja. Ožji območji obeh primorskih središč se pričakovano razmejujeta sredi Krasa, a presenetljivo velik delež anketirancev razširja koprsko "pokrajino" do Vršiča, novogoriško pa do Dragonje. Če izločimo rivalstvo obeh središč kot nestrokoven argument, ostaja očitno prisotna zavest o bolj ali manj enotnem območju, to je Primorski. "Trodelna" Slovenija ima očitno dovolj izrazite znake svojega obstoja.

\section{REGIJA, IZHODIŠČE ZA TEORETSKO OKREPITEV (SLOVENSKE) GEOGRAFIJE?}

V slovenski geografiji je vsebina pojma regija močno zanemarjena. Njeno razumevanje se na eni strani naslanja na preživela teoretska izhodišča, na drugi pa se nekritično prevzemajo pojmovanja drugih strok, predvsem ekonomije, sociologije in političnih ved. Resne teoretske obravnave pojma, izhajajoče iz spoznanj tujih raziskovalcev, bi doprinesle k sodobnejši, problemom primernejši in strokovno bolj suvereni naravnanosti geografskih preučevanj; to bi koristilo geografiji, pa tudi njeni aplikaciji, saj bi s svojimi pogledi na regijo bogatila poglede sorodnih strok. Na kratko si oglejmo nekatera dejstva, ki s pretiranim poenostavljanjem in nedoslednostjo posebno močno problematizirajo vsebino regije.

Kar pravilo je, da razlagalci definicije regije izpostavljajo poljubnost izbire kriterijev (eden ali več izbranih kriterijev). Zadeva dobi resen obraz, ko poljubnost izbire kriterijev (kazalcev) odenemo s plaščem znanstvenosti, ki pa nastopa z argumenti (akademske) moči; tako dobimo le (tragi)komedijo zmešnjav. Z arbitrarnim izborom kazalcev lahko povsem znanstveno rajoniramo, zoniramo, tipiziramo, ne pa regionaliziramo. Oglejmo si le dva primera nedosledne uporabe (mešanja) regionalizacije in tipizacije/rajonizacije. 
Pri izrazito formalističnem (mehanskem) pristopu k "regionalizaciji", ki se pogosto označuje kot "nova", avtorjev Gabrovca, Orožna Adamiča, Pavška, Perka in Topoletove, je izpostavljena Wardova metoda ugotavljanja stopnje podobnosti/sorodnosti (!). Regija naj bi bil po tej (in njej podobnim) logiki vsak del zemeljskega površja, ki je različen (v čem, kako?) od drugega. Če takšnemu "znanstvenemu" gledanju dodamo še načela, po katerih je bila izdelana "nova" regionalizacija (načelo enostavnosti, preglednosti, sistematičnosti in lahke razumljivosti), se moramo vprašati, kje je ostalo temeljno načelo: načelo strokovnosti?

V drugem primeru Kladnik (1996) povzema Ilešiča, da naravnogeografsko regionalizacijo lahko označimo kot regionalizacijo na podlagi meril tipologije naravnih pokrajin. Kaj je belo in kaj črno? Zadeva se zaplete do absurda ob Ilešičevi ugotovitvi (stari pol stoletja!), da je na našem planetu pojem čiste naravne regije že močno nerealen, abstrakten. Iz tega izhaja, da če bi hoteli regijo obravnavati kot naravno, bi si jo morali predstavljati takšno, kakršna je bila pred preoblikovalnimi učinki človekove dejavnosti. To pa je predmet historične (fizične) geografije. Iz tega mrtvega kota se potegne Ilešič kar sam s trditvijo, da so naravnogeografske regije $\mathrm{v}$ geografiji še vedno tako zelo pomembne, da jih lahko označimo za "geografske". Od vsega tega razglabljanja je edino resnično dejstvo to, da so naravne pokrajine (močno) preoblikovane. Tako lahko rečemo, da je regionalizacija resnične (dejanske, žive) pokrajine v izhodišču usmerjena k celovitemu pristopu.

Številne razprave o načelih regionalizacije imajo le eno napako: skoraj nič ne govorijo o objektu, to je o regiji. Peščeno uro slovenske geografije bo potrebno obrniti - na noge.

Strokovna neresnost se jasno pokaže pri strokovni terminologiji. Na področju regije obstaja prava zmešnjava (samovolja), saj je pogosto vseeno, kateri izraz uporabljamo: pokrajino, rajon ali regijo. Primer: pokrajina ali regija (Perko, 1998, str. 14).

Pri regiji je geografija izgubila verjetno svoj najmočnejši strokovni adut strokovne suverenosti. Podredila se je pogledom sorodnih strok pri reševanju praktičnih vprašanj. Geografi se pri vključevanju $\mathrm{v}$ interdisciplinarno delo srečujemo $\mathrm{z}$ različno interpretacijo istih pojmov. Žal se skoraj po pravilu dogaja, da je prav geografska strokovna suverenost najšibkejša in se zelo hitro priliči/podredi drugim strokam. Poučen je pristop Ravbarja (2004), ki $\mathrm{v}$ uvodu razprave izpostavlja geografske dejavnike, ki vplivajo na oblikovanje regij (pokrajinsko pestrost, zavest ljudi, razpršenost poselitve). Geografsko stvarnost slovenskih pokrajin pa potem zavrača na račun utilitarističnih (gospodarskih) razlogov. Logistične probleme upravljanja ozemlja meša z geografsko vsebino regij. Kljub temu, da s številnimi argumenti opredeljuje prednosti večjega števila (obstoječih, delujočih) manjših pokrajin, se takoj nato zavzema za preprečevanje "drobnih lokalizmov" in za "primerljivost s soseščino". S tem je avtor izstopil iz geografskega kroga in se spustil na področje (državne) uprave. Vendar drame še ni konec. Nov zaplet povzroči Ravbarjev (geografski) občutek, da bodo pokrajine morale izhajati iz temeljnih geografskih potez Slovenije (!?), to je njene naravne in družbene pestrosti, že izoblikovane hierarhije oskrbnih središč in regionalne zavesti prebivalstva; zaključek, ki bi moral biti izhodišče obravnave. Članek bo kljub vsemu dodan k avtorjevi bibliografiji kot znanstven; kaj pa povrhu vsega pomeni naslov članka, ostaja neznanka.

Ker se pristopi k členitvi zemeljskega površja med seboj mešajo, iz poljubnosti izbora kazalcev izhaja množica vprašanj, o katerih nekateri pišejo globokoumna razglabljanja (samogovore). Pogosto pa razglabljanje pripelje do usodnega vprašanja: katera regionaliza- 
cija je torej pravilna? Kako to presoditi? Drozg (2004, str. 22) odgovarja, da objektivnega odgovora ni, ker je vprašanje retorično (?). To je žal realna slika slovenske geografije, ki zahaja v idealistične in metafizične vode. Duh časa (kako ga izmeriti?) naj bi po mnenju istega avtorja poleg metodologije dela pomagal pri regionalizaciji.

Kako naj razumemo trditev, da je v dejanski pokrajini vsesplošno ujemanje (posameznih prvin) redko? Kot da bi bila pokrajina zgrajena iz med seboj ločenih plasti. Kaj pa soodvisnost (sovisnost) med pokrajinskimi prvinami? Ali ravno ta odnos ne oblikuje pokrajine? Po logiki stvari bi morali postaviti $\mathrm{v}$ ospredje preučevanja učinke odnosov, razmerij med pokrajinskimi "elementi". Strogo formalistično se lahko vprašamo, kje sploh lahko najdemo čiste pokrajinske elemente, saj so že v osnovi sad (so)učinkovanja ostalih pokrajinskih elementov.

Podobno z metafiziko prežetim gledanjem imamo opravka pri trditvah, da "regije oblikujemo" ali "združujemo in ločujemo pokrajinske enote". Le od kod nekaterim geografom takšna božanska moč? Geografija preučuje (raziskuje, ugotavlja, meri) zemeljsko površje in si prizadeva ugotavljati njene značilnosti (zakonitosti). Tako naj bi tudi iskali/preverjali (ne)obstoj regij v okviru širših nalog preučevanja zgradbe (organiziranosti) zemeljskega površja.

Zaradi odsotnosti opredelitve regije, torej zaradi pomanjkanja (geografske) teoretične osnove, so tovrstne razprave podobne zboru, $\mathrm{v}$ katerem vsi govorijo, posluša pa nihče. Na žalost sta v slovenski geografiji za razumevanje vsebine regije kot trdnjavi močni dve avtoriteti: Ilešič in Vrišer, kot dopolnilni pa še mogočni senci "praavtoritet" Ritterja in Hetnerja. Bogata tuja literatura (in življenje) je od teh pogledov premaknila čas vsaj za pol stoletja.

Kakorkoli gledamo na Ilešičeva prizadevanja po integraciji geografije: $\mathrm{z}$ nostalgijo, posmehom, pomilovanjem, ali z osebno zadrego, nam sodobna geografska misel ponuja orodje, da se integraciji približamo. Ilešičeva prizadevanja so bila v njegovem času anahronizem, saj takratni razvoj (slovenske) geografije objektivno ni omogočal prave integracije geografije. Ob tem pa je potrebno opozoriti, da so v 60. letih nastala dela, predvsem doktorske disertacije, ki so za tedanje razmere dosegla visoko raven "integriranosti geografije", na primer V. Klemenčič, 1959; Belec, 1968; Bračič, 1967; Gams, 1959; Pak, 1965; Jeršič, 1965; Vojvoda, 1965. Še več, v teoretičnem pogledu ta dela do danes niso bila presežena, zato lahko govorimo le o strokovnem epigonstvu sodobnikov (na primer delo Topoletove, 1998). Čas je za poskuse sodobnega "integriranega" pristopa k preučevanju pokrajine.

Glede na specifične oblike razvoja (organiziranosti) sodobne pokrajine menimo, da je ravno regija tisti mobilizacijski dejavnik, ki bi s svojo celovitostjo vzpodbudil razglabljanja o pristopih k celovitejšemu preučevanju pokrajine. Popolnoma se strinjamo z izjavo Drozga (2004, str. 24): "Regija - kontekst in koncept spoznavanja pokrajine.", ne pa tudi z njegovim razumevanjem vsebine. Drozgu pomeni regija le orodje, deklo, delovni pripomoček za spoznavanje pokrajine. Naše prepričanje je, da je regija geografska stvarnost; še več, najvišja oblika "zrelosti" razvoja pokrajine.

Regija ni sam po sebi način organiziranja geografskega prostora, ampak je njegova posledica, nadgradnja. Zato se nam zdi Natkov pogled (1998, str. 142), da geografi potrebujemo predvsem nove kvantitativne metode regionalizacije, s katerimi se bomo znebili bremena subjektivnosti, zgrešen; razjasniti moramo najprej vsebino regije, potem bo izbor 
metodologij enostaven. Ker pa so regije v različnih razvojnih stadijih, jih le redko najdemo $\mathrm{v}$ idealnih oblikah. Zato naj bi regija poleg cilja preučevanja postala tudi teoretskometodološki pripomoček, dodana vrednost, ki bi obogatila geografske raziskave in jim dala novo moč pri suverenejšem vključevanju geografije na tržišče znanosti. Prej ali slej bi zamrle tudi izrazito ideološke (nestrokovne) zahteve po dajanju enake teže (število ur, strani itn.) fizični in družbeni geografiji; merjenje njunih razmerij z lekarniško tehtnico bi bilo komično, če ne bi bila s tem tragično prizadeta geografija. Regija bi po našem mnenju morala postati meta koncept geografije, njena osrednja vsebina, v kateri bi se zrcalila pokrajinska celovitost. $\mathrm{V}$ tem nas potrjuje Einsteinov pristop, ki je z miselnim procesom povezal do tedaj tri ločena področja fizike: mehaniko, elektrodinamiko in termodinamiko $\mathrm{v}$ enoten sistem in na tej osnovi omogočil novo, celovitejše in bolj poglobljeno razumevanje temeljnih fizikalnih zakonov.

Opozoriti pa moramo na nevarnost, ki preti poglobljenemu teoretskemu delu v (slovenski) znanosti, posebno na ravni univerzitetnega izobraževanje; "bolonjski proces" prenove študijskih načrtov univerzitetno raven študija z dolgo, večstoletno tradicijo in izkušnjami, znižuje na visokošolsko-strokovno stopnjo. Upravičen je strah, da se bo nikoli dovolj teoretično poglobljena obravnava strokovnih problemov zožila na plitvo tehnicistično-aplikativno smer, s tem pa se bo močno skrčilo zanimanje (potreba?) po teoretičnih vprašanjih stroke.

\section{Literatura}

Abel, C., 2000. Architecture \& Identity - Response to Cultural and Technological Change. Architectural Press, Oxford, 270 str.

Bailly, A., Ferras, R., 1997. Éléments d'épistemologie de la géographie. Armand Colin, 191 str.

Belec, B., 1968. Ljutomersko-ormoške gorice: agrana geografija. Obzorja Maribor, 291 str.

Bird, J., 1993. The Changing Worlds of Geography. Clarendon Press, 307 str.

Bračič, V., 1967. Vinorodne Haloze: socialnogeografski problemi s posebnim ozirom na viničarstvo. Maribor, Obzorja, 251 str.

Brenner, N., 2001. The limits to scale? Methodological reflections on scalar structuration. Progress in Human Geography 25, str. 591-614.

Bufon, M., 1999. Problematika teritorialnosti v politični in kulturni geografiji. Geografski vestnik 71, str. 91-103.

Butz, D., Eyles, J., 1997. Reconceptualizing senses of place: social relations, ideology and ecology. Geografiska Annaler 79 B, 1, str. 1-25.

Chapman, G., P., 1977. Human and Environmental Systems: a Geographer's Appraisal. Academic, 421 str.

Claval, P., 1995. Initiation à la géographie régionale. Nathan, 288 str.

Claval, P., 1998. An introduction to regional geography. Blackwell, 299 str.

Coffey, W., 1992. Géographie, économie, science régionale. V: Encyclopédie de géographie. Economica, str. 159-175. 
Černe, A., 1987. Regionalne razlike in regionalni razvoj. V: Teorija in metodologija regionalne geografije. Oddelek za geografijo in Znanstveni inštitut Filozofske fakultete Univerze Edvarda Kardelja v Ljubljani (Dela 4), str. 73-79.

Černe, A., 1999. Prostorska identiteta - koncept različnosti. Anthropos 4-6, str. 296-300.

Drozg, V., 2004. Regija - kontekst ali koncept spoznavanja pokrajine. V: Teorija in praksa regionalizacije Slovenije. Univerza v Mariboru, Pedagoška fakulteta, str. 16-24.

Dumolard, P., 1975. Région et régionalization. Une approche systémique. L'Éspace Géographique 4, 2, str. 93-111.

Encyclopédie de géographie, 1992. Bailly, A.; Ferras, R.; Pumain, D. (ur.). Economica, Paris, 1132 str.

Ferras, R., 1986. Écrire de la géographie régionale sur l'Espagne. L'Éspace Géographique 4, str. 283-288.

Gams, I., 1959. Pohorsko Podravje: razvoj kulturne pokrajine. SAZU, 231 str.

Gams, I., 1977. Regionalna geografija - vrh ali anahronizem metodične geografije. Geografski obzornik 24, 1-2, str. 41-45.

Gams, I., 1984. Metodologija geografske razčlenitve ozemlja. Geografski vestnik 56, str. 75-82.

Gams, I., 1987. Regionalna geografija - teorija in praksa. V: Notranjska. Zbornik 14. zborovanja slovenskih geografov, Postojna, ZGDS, str. 9-12.

Gams, I., 1994. Pojem in obseg doline v slovenski regionalni geografiji. Geografski vestnik 66 , str. 125-136.

Gams, I., 2000. Stanje v (prirodno)geografski regionalizaciji Slovenije. Geografski vestnik 72,1 , str. 53-60.

Gams, I., 2001. Regionalizacija Slovenije in pouk. Geografija v šoli 10, 1, str. 9-13.

Gilbert, A., 1988. The new regional geography in English and Frenc-speaking countries. Progress in Human Geography 12, 2, str. 208-228.

Hartshorne, R., 1946 (druga izdaja). The nature of geography. A critical survey of current thought in the light of the past. Association, Lancaster, Pennsylvania, 482 str.

Hägerstrand, T., 1975. "Survival and Arena". The Monadnock 49, June, Clark University Geographical Society.

Holmen, H., 1995. What's new and what's regional in the "New Regional Geography"? Geografiska Annaler 77 B, 1, str. 47-64.

Ilešič, S., 1958. Problemi geografske rajonizacije ob primeru Slovenije. Geografski vestnik 29-30, str. 83-140.

Ilešič, S., 1972. Slovenske pokrajine. Geografski vestnik 44, str. 9-31.

Ilešič, S., 1979. Pogledi na geografijo. Partizanska knjiga, Ljubljana, 612 str.

Jeršič, M., 1965. Družbena geografija Blejskega kota: doktorska disertacija. Oddelek za geografijo Filozofske fakultete Univerze v Ljubljani, 313 str.

Johnston, R. J., 1991. A question of place. Oxford, Blackwell.

Jones, K. T., 1998. Scale as epistemology. Political Geography 17, str. 25-28.

Keating, M., 1998. The New Regionalism in Western Europe. Cheltenham, Elgar.

Kladnik, D., 1996. Naravnogeografske členitve Slovenije. Geografski vestnik 68, str. 123160. 
Klemenčič, M. M., 1987. Sistemska teorija: pot k novi regionalni geografiji? V: Teorija in metodologija regionalne geografije. Oddelek za geografijo in Znanstveni inštitut Filozofske fakultete Univerze Edvarda Kardelja v Ljubljani (Dela 4), str. 32-40.

Klemenčič, M. M., 1995. Krajevna identiteta na primeru Srednje in Zgornje Gorenjske. V: Geografska problematika slovenskega alpskega sveta in slovenskih mest (Dela 11), Oddelek za geografijo Filozofske fakultete Univerze v Ljubljani, str. 47-58.

Klemenčič, M. M., 1997. A case study of regional identity problems in Slovenia. V: Einzelhandelsentwicklung Zielorientierte Regionale Geographie (ur. Klaus Wolf \& Elke Tharun). Institut für Kulturgeographie, Stadt- und Regionalforschung der J. W. Goethe- Universität, Frankfurt am Main, str. 87-96.

Klemenčič, M. M., 1998. Drago Perko in Milan Orožen Adamič (glavna urednika): Slovenija - pokrajina in ljudje. Ljubljana 1998, Založba Mladinska knjiga. Geografski vestnik 70, str. 205-209.

Klemenčič, M. M., 2002. Miselna slika pokrajin. V: Spoznavni zemljevid Slovenije. Polič, M. (ur.). Znanstveni inštitut Filozofske fakultete v Ljubljani, str. 161-180.

Klemenčič, M. M., 2003. Civilizacijske razvojne stopnje in razvojni problemi obrobnih območij v Sloveniji. V: Priložnosti in možnosti regionalnih struktur na poti k združeni Evropi. Oddelek za geografijo Filozofske fakultete Univerze v Ljubljani (Dela 19), str. 153-164.

Klemenčič, M. M., Lipovšek, I., 2002. Geografija Slovenije 1. Učbenik za 3. letnik gimnazij. DZS, 107 str.

Klemenčič, V., 1959. Pokrajina med Snežnikom in Slavnikom. SAZU, 197 str.

Klemenčič, V., Zupančič, J., 1992. Regionalizem-nov izziv za geografijo. Primer slovenskega etničnega ozemlja. Geografski vestnik 64, str. 157-167.

Kušar, S., 2003. Problemska regija kot element za zasnovo regionalnega razvojnega programa: magistrsko delo. Univerza v Ljubljani, Filozofska fakulteta, Oddelek za geografijo, 140 str.

Kušar, S., Vintar Mally, K., 2004. Ljubljanska urbana regija - problemska regija. V: Geografska problematika Ljubljane in Zagreba. Oddelek za geografijo Filozofske fakultete Univerze v Ljubljani (Dela 22), str. 15-26.

Malovrh, V., 1958. Prispevek gospodarsko-geografskemu rajoniranju Jugoslavije. Ekonomska revija 3, 2, str. 81-96.

Marconis, R., 1996. Introduction à la géographie. Armand Colin, 222 str.

Minshull, R., 1967. Regional geography. Hutchinson University Library, 168 str.

Moser, W., 1975. Einige Erfahrungen mit dem Tourismus in den Alpen - das Oekosystem Obergurgl. Schriftenreiche des Alpen - Instituts Munchen, H. 3.

Murphy, A., B., 1991. Regions as social constructs: the gap between theory and practice. Progress in Human Geography 15, 1, str. 23-36.

Natek, K., 1998. O regionalizaciji Slovenije. Geografski vestnik 70, str. 139-150.

Nir, D., 1987. Regional Geography Considered from the Systems'Approach. Geoforum 18, 2, str. 187-202.

Nir, D., 1990. Region as a Socio-environmental System. An Introduction to a Systemic Regional Geography. Kluwer Academic Publishers, 182 str. 
Paasi, A., 1986. The institutionalization of regions: a theoretical framework for understanding the emergence of regions and the constitution of regional identity. Fennia 164:1, str. 105-146.

Paasi, A., 1996. Territories, boundaries and consciousness: the changing geographis of the Finnish - Russian border. John Wiley \& Sons, cop., 353 str.

Paasi, A., 2002. Bounded spaces in the mobile world: deconstructing "regional identity". Tijdschrift voor economische en sociale geografie 93, 2, str. 137-148.

Paasi, A., 2002a. Place and region: regional worlds and words. Progress in Human Geography 26,6 , str. 802-811.

Paasi, A., 2003. Region and place: regional identity in question. Progress in Human Geography 27,4 , str. $475-485$.

Paasi, A., 2004. Place and region: looking through the prism of scale. Progress in Human Geography 28, 4, str. 536-546.

Pak, M., 1965. Družbenogeografski razvoj Zg. Dravskega polja: doktorska disertacija. Oddelek za geografijo Filozofske fakultete Univerze v Ljubljani, 277 str.

Perko, D., 1992. Geografski informacijski sistemi v regionalni geografiji in geoekologiji. V: GIS v Sloveniji. Oddelek za geografijo Filozofske fakultete v Ljubljani (Dela 9), str. 186-203.

Perko, D., 1998. The regionalization of Slovenia. Regionalizacija Slovenije. Geografski zbornik 38, str. 11-57.

Perko, D., 1998. Geografija, regija in regionalizacija. V: Slovenija, pokrajina in ljudje. Perko, D.; Orožen Adamič, M. (ur.). Mladinska knjiga, str. 12-15.

Petek, F., 2004. Spremembe rabe tal v 19. in 20. stoletju v slovenskem alpskem svetu: doktorska disertacija. Univerza v Ljubljani, Filozofska fakulteta, Oddelek za geografijo, 342 str.

Philbrick, A. K., 1957. Principles of areal functional organization in regional human geography. Economic Geography 33, 4, str. 299-336.

Pinchemel, P. \& G., 1992. La face de la terre. Armand Colin, 519 str.

Plut, D., 1977. Fizičnogeografska regionalizacija Koprskega Primorja s pomočjo faktorske analize. Geografski vestnik 49, str. 165-171.

Plut, D., 1999. Regionalizacija Slovenije po sonaravnih kriterijih. Geografski vestnik 71, str. 9-25.

Pokrajine v Sloveniji. 1999, Vrišer, I. (ur.). Vlada Republike Slovenije, Služba za lokalno samoupravo, Ljubljana, 126 str.

Radinja, D., 1989. O terminološki problematiki v slovenski geografiji. V: Geografija in aktualna vprašanja prostorskega razvoja. Oddelek za geografijo Filozofske fakultete Univerze Edvarda Kardelja v Ljubljani (Dela 6), str. 185-195.

Ravbar, M., 2004. Regional Development in the Regional Division of Slovenia (Regionalni razvoj v pokrajinski členitvi Slovenije). Acta Geographica Slovenica - Geografski zbornik 44, 1, str. 7-24.

Reynolds, D., R., 1994. Political geography: the power of place and the spatiality of politics. Progress in Human Geography 18, 2, str. 234-247. 
Sagan, I., 2004. Looking for the nature of the contemporary region. Progress in Human Geography 28, 2, str. 141-144.

Slovar slovenskega knjižnega jezika. 1994, DZS, Ljubljana, 1714 str.

Slovenija, pokrajina in ljudje. 1998 Perko, D.; Orožen Adamič, M. (ur.). Mladinska knjiga, 1998, 735 str.

Spoznavni zemljevid Slovenije. 2002. Polič, M. (ur.). Znanstveni inštitut Filozofske fakultete v Ljubljani, 2002, 381 str.

Steiner, D., 1979. Systemtheory/Systemanalyse und Geographie. Geographische Zeitschrift 67, 3, str. 185-210.

Straussfogel, D., 1997. World-System Theory: Toward a Heuristic and Pedagogic Conceptual Tool. Economic Geography 73, 1, str. 118-130.

Taylor, R. J., 1982. A materialist framework for political geography. Transactions of the Institute of British Geographers NS 7, str. 15-34.

Teorija in metodologija regionalne geografije. 1987. Pak, M. (ur.). Oddelek za geografijo in Znanstveni inštitut Filozofske fakultete Univerze Edvarda Kardelja v Ljubljani (Dela 4). $240 \mathrm{str}$.

Topole, M., 1998. Mirnska dolina: regionalna geografija porečja Mirne na Dolenjskem. Znanstvenoraziskovalni center SAZU, 174 str.

Uitermark, J., 2002. Re-scaling, "scale fragmentation" and the regulation of antagonistic relationship. Progress in Human Geography 26, 6, str. 743-765.

Vedenin, Ju. A., 1990. Problemy formirovanija kulturnogo landšafta i ego izučenija. Serija geografičeskaja 1, Akademija nauk SSSR, Moskva, str. 5-17.

Vojvoda, M., 1965. Razvoj kulturne pokrajine v Bohinju: doktorska disertacija. Oddelek za geografijo Filozofske fakultete Univerze v Ljubljani, 204 str.

Vrišer, I., 1987. Zapis o regionalni geografiji. Geografski vestnik 59, str. 127-131.

Vrišer, I., 1990. Ekonomska regionalizacija republike Slovenije. Geografski zbornik 30, str. 129-247.

Vrišer, I., 1996. Regija. Enciklopedija Slovenije, 10. zV., Mladinska knjiga, str. 144-145.

Vrišer, I., 1996. Regionalizacija. Enciklopedija Slovenije, 10. zv., Mladinska knjiga, str. 145-148.

Vrišer, I., 1997. Regionalizacija Slovenije. IB revija 31, 9-10-11, str. 6-17.

Vrišer, I., 1999. Regionalizacija. V: Pokrajine v Sloveniji. Vrišer, I. (ur.). Vlada Republike Slovenije, Služba za lokalno samoupravo, str. 38-63.

Vrišer, I., 2002. Uvod v geografijo. Oddelek za geografijo Filozofske fakultete v Ljubljani, $414 \mathrm{str}$.

Whittlesey, D., 1954. The regional concept and the regional method. American Geography: Inventory and Prospects. James \& Jones.

Wishart, D., 2004. Period and region. Progress in Human Geography 28, 3, str. 305-319.

Zupančič, J., 2003. Ključni problemi ohranjanja in razvoja narodne identitete. V: Slovenija in nadaljnji razvoj Evropske unije. CRP, zaključno poročilo. Inštitut za narodnostna vprašanja, Ljubljana in Znanstvenoraziskovalno središče RS, Koper, nosilec Zupančič J., str. 40-64. 


\section{REGION AND REGIONAL STRUCTURE OF SLOVENIA}

\section{Summary}

Despite of the fact that region is one of the basic geographical concepts, its contents is the least clear of all; even more, no other concept is subject of such various, usually controversial comprehensions. In this paper the central character of the region in geography is pointed out, which gives hope for the more comprehensive treatment of the land surface or, according to Ilešič, for a certain form of reintegration of geography.

In the first part of the paper the principal views as to the region are presented, as established in the world geography and, furthermore, key terms, dilemmas and problems, related to the concept of the region, are emphasized. Aiming at better transparency of the subject and presentation of differences in the understanding of the content of the region within the last half of the $20^{\text {th }}$ and the beginning of the $21^{\text {st }}$ century, the viewpoints of two experts are emphasised: Hartshorn and Paasi. This is followed by a number of viewpoints of foreign geographers as regards the region, so as to acquire as extensive insight in the diversity of comprehension of the content of the region as possible. In the second part an attempt is made to critical discuss the region in Slovene geography, from the theoretical as well as from the practical point of view (regionalization).

Some elements which are essential to be taken into account when defining regions in Slovenia, are indicated. And finally, some viewpoints are given, which indicate directions of the (supposed) development of regions in Slovenia.

\section{REGION FROM HARTSHORNE TO PAASI}

In addition to the review of the principal approaches to regional geography and the region, Harsthorne is also credited with having pointed out and defined the most important terms related to the region: criteria for regionalization, limits, uniqueness, unity. The Hartshorne's approach to the region is chorological: region is an area of specific location, differing in a certain way from other areas, and the extensiveness of which corresponds to such differentiation. However if looking at the landscape from a much broader aspect, there would not be much exaggerating in declaring that Hartshorne stuck to formalistic (positivistic) approach. He considered regionalization first of all as a means for carrying out the researcher's views (concepts) of the landscape. Such view represents the rounding up of the last century's concepts of the region. Intensive socio-economic and spatial changes in the last half of the century changed the subject matter of the region: an anonymous, randomly selected part of the land surface (object) has been changed into an important spatial link (subject).

A work similar to that done by Harsthorne in respect to the whole geography was done by Paasi for the region. He carried out a thorough examination of contextual, theoretical and methodological viewpoints of the region, as appeared in the world literature from about the end of the Second World War. But Paasi went much further: he established his own view of the region, its nature and development. His work is of particular importance since he made a considerable contribution to the renaissance and revaluation of the region 
in the world geography. For almost the whole second half of the $20^{\text {th }}$ century regional geography was put in the shade/disfavoured by "contemporary" geographical concepts. During this period it was, together with the region, in a somehow novercal position by the science, someone considered them even as fossils or needless ballast. Only few individuals made attempts for theoretical treatment of regional geography. Regions were subject to some selfwilled determinations; thus their treatment actually became non-scientific. The praxis which was mainly still applied in regional geography was to accumulate a huge amount of data and to describe such data, in the absence of theory.

According to Paasi, regions are complicated institutional structures (institutionalised facts), since they are based on social agreements and institutions, such as media, education system, political organisations, government and economy; the majority of these operating through the regional level. Formation of a region always involves normative components, since institutional structures are the structures of rules, powers and beliefs, within which symbols and institutions appear through material praxis. When these are established, they became a social fact, since starting of their operation depends on peoples' beliefs and on the time of their playing a role in the public space and with governments. Such operation within the region may be at the same time reproduction, maintenance of the situation and transformation (Paasi, 2002a, p. 806). Formation of identity should be associated with three processes, conducted simultaneously and being indicated by:

- territoriality (boundaries emerging as a result of various social activities, separating the region and identity from the neighbouring regions),

- $\quad$ symbolism (name of the region and many other symbols, reflected in economy, culture, media and with government),

- $\quad$ institutionalism (institutions, maintaining symbol forms and at the same time differentiation between regions) (Paasi, 2002, p. 140).

\section{NEW REGIONAL GEOGRAPHY}

Exposing the "new regional geography" from the middle seventies of the $20^{\text {th }}$ century became a subject of great interest in the world geographical literature. This was due to many reasons. First steps of the renaissance of regional geography, which strived to (re)define basic concepts in regional geography (scale, space, site, locality, region), were suddenly associated with viewpoints, promising a geographical eldorado. The novelty excited great interest, which was followed by a thorough critical discussion of the starting points of the new prospect on the regional geography. The first impression is that many modern regional geographers were at least partially "infected" by new ideas, which is owed in particular to the fact that these represent a response to the contemporary socio-economical and political conditions.

In their self-representation those who speak in favour of the new regional geography mainly deny any connection whatsoever with the traditional geography, which is "isolationistic, descriptive, static, reactionary and theoretically bankrupt"; its treating the region is supposed to be passive as the "container of phenomena", and it is supposed to range no further than to the study of spatial differences. 
Gilbert's (1988, p. 209) definition of the main directions of the new regional geography are the following:

- a region as the focus point of identification (specific series of cultural relationships between a group of people and individual places);

- a region as a media for social interactions (exposure of the activity of social relationships results in political prospect of the region);

- a region as a local response to capitalist processes.

As per opinion of Gilbert, the latter definition should be the most appropriate for the new geography. This also indicates that the new regional geography should not be a tool for getting to know the world in the first place but a tool for a concrete action. The new regional geography is usually inspired with radicalism.

According to Holmen, the radical new geography was catched into the same trap as spatial sciences: single-causal prospect of the world, with a presumption that basic principles of spatial organisation are always the same. However the new geography should be acknowledged its striving for the development of theory, which is unlike the essential part of the traditional regional geography, which starts with describing a landscape and only after that tries to find the sense. This creates a risk that we see what we like to see and we act as we are used to. The traditional regional geography therefore lacks theory. Holmen's warning should be considered at this point, that theory does not represent a problem but its application method. For every serious understanding of whichever place it is essential to look in the past, however preserve the wide prospect and place the object under research in a wide frame (Holmen, 1995, p. 60).

\section{REGION IN SLOVENE GEOGRAPHY}

Like every serious geographical study, also the Slovene geography could not have avoided the term region. In the contrary many geographers felt a need and obligation to determine the concept. The region was discussed even more indirectly, through the treatment of regionalization, which constantly caused a great deal of interest and vigorous response among Slovene geographers. We may hereby mention the related consultation on the theory and methodology of the regional geography in 1987 in Ljubljana.

Ilešič was the person who was the most intensively involved in the problematic of region (and regionalization). His tendencies kept abreast with his efforts for the reintegration of geography, meaning the comprehensive dealing with the Earth's surface contrary to dividing geography into individual branches, which was becoming more and more expressive. In addition to Ilešič, also Gams was interested in the determinations of spatial units. He tried to set a line of separation between the terms: space, zone, belt, territory, area, province, district, landscape, region (1984). He strives for the uniform geographical terminology or for the discontinuation of the too-loose indications in favour of some terms in the sense one word for one meaning. According to his proposal, region should be used for sociogeographical complex in the contrast to landscape, which is to represent a natural-geographical complex. Due to his professional authority, a definition of Vrišer got almost a 
dogmatic meaning: "Region is a landscape of bigger or smaller size, expressing certain originality as regards the prevailing natural and social phenomena or reflecting their intertwining, which makes them distinguishable from the neighbouring lands." (Vrišer, 1997, p. 6).

\section{REGIONS AND REGIONALIZATION OF SLOVENIA}

Most discussions related to the nature of a region become clear when looking at individual regionalizations. We studied four the most exposed ones: two economic-geographical (Ilešič, 1958; Vrišer, 1990), geographical (Ilešič, 1972) and close-to-nature managed (Plut, 1999). What excited our interest in relation to the said regionalizations was first of all boundaries between the biggest regions (macroregions) and their number. Both components of regionalization should present the internal organization of Slovene landscape and the level of stability of regional units.

Coincidence (overlapping) of the regions' boundaries among the treated regionalizations is considerable. The course of boundaries of the biggest, (macro) regional units indicated their triple nature; they are based on geographical boundaries (mountainous/hilly ridges or watersheds), on historical administrative borders and on boundaries between gravitational areas. The last reason seems to be the most expressive. The majority of boundaries are clearly Dinaric-oriented, which is a result of geological structure of the Slovene teritorry. These boundaries follow mountain ridges or watersheds, which were used as the basis for mediaeval administrative (provincial) and recent municipal boundaries.

The discussed reference regionalizations involve a different number of basic (macro) regions: that of Ilešič 5, of Vrišer 12 and of Plut 8 . Ilešič applied the urban system, which was in the sixties and seventies subject to rather weak development, in particular on the level of regional centres. On the basis of their strengthening different spatial relations were established, which are taken into consideration by the recent two regionalizations. This is to raise a question of hierarchical division of Slovene regions. Does any another basic structuring exists, which may be applied for the Slovene territory? Considering the historical development, administrative arrangement from the Middle Ages on, economic structure, cultural aspects and identity, Slovenia should be consisted of three units: Eastern Slovenia, Central Slovenia and Western Slovenia; if expressed in the national language, based on the historical administrative units, these would be called Štajerska (including Koroška and Prekmurje), Kranjska (without a part of Notranjska) and Primorska. Mountain passes Trojane and Postonjska vrata are to keep the function of symbolic delimiting lines among the said three units of Slovenia. The mentioned provincial identity of all three units has been developing for at least half of millennium and has been supported by natural-geographical boundaries, economic development and centres; if looking from this point of view only Primorska may be excepted, the centre of which would organically be Trieste.

Recent development of transport infrastructure and strengthening of regional centres (establishment of new universities and higher education centres) indicates a new motion in the strengthening of socio-economic power and consequently the identity on the regional level. This may be noticed also through the tendencies of Church, which considers the possibility of replacing the present three big dioceses by formation of few smaller ones. 


\section{FACTORS OF (TRANS)FORMATION OF SLOVENE REGIONS}

Slovenia is the whole world in small. Due to its natural-geographical conditions, historical development, variegated neighbourhood regarding culture and nationality, and economicpolitical development, the regional structure of Slovenia could not be compared to structures of other countries and could not be approximated to these. A distinction should be made between professional and applicative standpoint in relation to regions. Slovenia is considered as speciality among European countries also with regard to the structure of regional identity. The mosaic landscape, ethnographical, cultural, dialectical, economical, historically-administrative and other differences gave rise to the formation of regions at different hierarchy levels, the extent of which can not be compared to regions in other European countries.

In order to understand what is happening in a landscape, general developmental (civilisational) stages of the society (Klemenčič M. M., 2003) should be taken as a starting point, that indicates which problems of spatial development are pointed out. Development of a society results in the widening of the circle of development factors and consequently in the decreasing of the closeness (self-sufficiency) also of very small areas. When searching for the patterns of organization and development of the landscape in the light of the region, the focus is on the discussion of the principal developmental factors. The short-term and episodic developmental factors should be eliminated, so as to bring to light the enduring (more substantial) ones. The nature of regions is determined by wider socio-economic conditions: their dimension, structure, mode and level of their connection with the neighbouring regions, etc. If simplifying and generalising the conditions of the last century, three kinds (stages) of socio-economical conditions could be determined, which formed the organization of the space and thus the region: agrarian, industrial and informational (globalised).

Agrarian period indicates close relation between natural conditions and the mode of economic use. Economical orientation of the majority of inhabitants was determined mostly by landscape types. Economically (agriculturally) homogenous areas were formed, which matched with the landscape types and in which local identity was formed. On a higher level, in particular in the provincial framework, through administrative functions, provincial identity was established (kranjska, štajerska, koroška, goriška), which was followed by the identity on a lower level (gorenjska, dolenjska, notranjska). The identity areas were clearly delimited by the means of natural and administrative borders.

Industrial period has already at the starting point rejected the precedent homogenous organisational set up of economy by means of gravitational organisational set up. New gravitational areas in Slovenia were characterised by economical and landscape heterogeneity, after the Second World War institutionalised in form of communal system. In the formation of spatial organisation an important part was plaid by central settlements of the fifth level by Vrišer. On account of coal industry and other industry, Zasavje became the only economically homogenous area in the industrial period, occupying the position in the hierarchical system of Slovene landscapes in a rather unfavourable manner due to the disproportion between the number of inhabitants and the concentration of economy on one side and the size of the land on the other side. In spite of the strong socio-economic transforma- 
tion and spatial reorganization, initiated by industrialization, local and regional identity was nevertheless preserved to a high degree.

Informational period (globalization period) contributed significantly to the loosening of internal connections of local areas. Openness to the world through numerous connections weakens the firmness of local/regional identify; weakens the attachment to home milieu, and the divides between identity areas are less and less clear. In globalization processes, Slovenia became a local area. On the other hand, it is through the politics of endogenous development (development from the bottom) that it endeavours to strengthen its local/regional identity, which is a principal factor of the policy of the kind. Dynamics and competitiveness of the socio-economic development are the reasons for the rapid change of the economic power of regions. Regional development factors (economists, politics, civil society associations) strengthten the need for development through, for example, establishment of higher education centres and the requirement for the establishment of an own administrative unit. Such development corresponds entirely to the scheme of ideal development of a region by Paasi. In such way, the middle (regional) level of hierarchy of regions is strengthening; first level (local) is represented by the areas on municipal level. The mentioned second level of hierarchy is represented by landscapes with a historically developed identity. The third (macroregional) level is associated with historic provinces (Štajerska, Kranjska) and the recently (trans)formed Primorska.

\section{CONSCIOUSNESS OF RESIDENTS TO DOMESTIC LANDSCAPE}

Within an interdisciplinary research carried out in the period from 1998-2000 (Polič et al., 2002) on peoples' conception of Slovenia and its development, also their notion of the extent of potential administrative units of the second level had been paid full attention too. The inhabitants under survey opted for the extent of landscape, to be controlled by a local centre. The results are most illustrative (M. M. Klemenčič, 2002), confirming almost completely the geographical concept (recognitions) of local/regional identity. Some of the findings:

- the residents' consciousness to domestic landscape is the most clearly formed;

- the smallest the area, the clearer the limitation of domestic landscape;

- people are still most aware of the old administrative borders.

The perspective in peoples' minds indicates two bases: on one side historical awareness, and on the other contemporary socio-economic and spatial processes. On macroregional level, distribution of Slovenia into three big (macro) units may be noticed, with their centres in Maribor, Ljubljana and Koper/Nova Gorica. Obviously, the existence of the "tripartite" Slovenia is thus distinct enough.

\section{LANDSCAPE-FUNCTIONAL UNITS OF SLOVENIA}

Division of Slovenia on the basis of river basins is probably the most credible. There are five river basins in the territory of Slovenia, which run parallel and in a Dinaric direction: soško-reško, savsko, savinjsko, dravsko and mursko. The said basins with their landscape structure of plains and valleys enabled the development of the local economic and urban 
system. Supporters of development of river basins are central settlements by Vrišer, with the exception of Ljubljana and Maribor, the importance of which increased on the account of the size of gravitation area and specific (administrative-traffic) position. Therefore the gravitation aspect got into the function of the supporter of development and also a factor of the strengthening and forming the local/regional identity. The residents' loyalty based on historical provinces is continued within the framework of gravitational centres of bigger supply centres.

After the division of economic and administrative units in the Middle Ages, natural, in particular relief conditions came in the role of delineation lines between bigger spatial units, mostly in the administrative (provincial borders), however also in the economic point of view; Gorenjska, Dolenjska and Notranjska had been characterised to a great extent by landscape and economic homogeneity. In the present times, the divides became even more distinctive delineation lines between landscape units as in the past; this holds good also for Notranjska, Spodnje Posavje and Pomurje.

Recent development, in particular of the road infrastructure, contributes to the more permeable borders with neighbouring countries. Such logic should result in the connection of areas and the formation of bigger functional units. In the Slovene case, a tripartite scheme may be envisioned, with the following centres: Maribor (Štajerska with Prekmurje and Koroška), Ljubljana (central-Slovene area, Kranjska), Koper-Nova Gorica (Primorska). As regards the latter, the strengthening of both centres is possible, through the cross-border cooperation.

\section{REGION, A STARTING POINT FOR THE THEORETICAL STRENGTENING OF (SLOVENE) GEOGRAPHY?}

In Slovene geography, the content of the term region is highly neglected. Its understanding is, on one hand, based on the past theoretical grounds and on the other hand understandings of other branches of profession are taken over free of any criticism, in particular economy, sociology and political sciences. Serious theoretical discussions of the term on the basis of the knowledge of foreign researchers would contribute to geographical studying which would be more contemporary, problem-adapted and more professionally sovereign; this would be of benefit to geography and also to its application since its viewpoints regarding the region would enrich the viewpoints of the related branches of profession. However it is almost by the rule that geographical professional sovereignty is the weakest and is therefore soon subjected to other professional branches.

Considering the efforts of Ilešič for the integration of geography: with nostalgia, derision, pity or personal embarrassment, the contemporary geographical notion provides an instrument for getting closer to the integration. In the sixties and seventies of the $20^{\text {th }}$ century the efforts of Ilešič were regarded as anachronism since the development of (Slovene) geography of that time which involved the development of individual geographical branches, did not provide for the real integration of geography. Regarding the specific forms of development (organisation) of modern landscape we are of the opinion that a region is a mobilisation factor which would, through its integrity, stimulate deliberations regarding the approach to the more integral studying of the landscape. 